\title{
ILIINOIS
}

Natureal

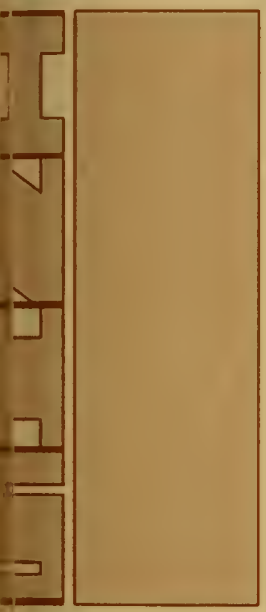

Hald F. Labisky

Vliam L. Anderson
Fistory

Survey

\section{Nutritional Responses of Pheasants to Corn, with Special Reference to High-Lysine Corn}

MATURAL HISTORY SURYEY

NOV 141973

LIBRARY

IE OF ILLINOIS

IEARTMENT OF REGISTRATION AND EDUCATION

IUURAL HISTORY SURVEY DIVISION BANA, ILLINOIS

THE LIBRARY OE THE 



\section{ILIINOIS}

\section{"atural Fistory Survey BULLETIN}

\section{Nutritional Responses of Pheasants to Corn, with Special Reference to High-Lysine Corn}

onld F. Labisky

lilam L. Anderson

EFRTMENT OF REGISTRATION AND EDUCATION

AURAL HISTORY SURVEY DIVISION RANA, ILLINOIS 
Dean Barringer, Ph.D., Chairman; Thomas Park, Ph.D., Biology; L. L. Sloss, Ph.D., Geology; (Vacant), Chemietry: RoBerT H. ANOERson, B.S.C.E., Engineering; Charles E. OLMSTEO, Ph.D., Forestry; W. L. EveriTt, E.E., Ph.D., Representing the President of the University of Illinois; RoGER E. BEYLER, Ph.D., Repreanting the Prcsident of Southern lllinois University.

\section{NATURAL HISTORY SURVEY DIVISION, Urbana, Illinois}

SCIENTIFIC AND TECHNICAL STAFF

George Sprugel, JR., Ph.D., Chief

ALICE K. ADAMS, Secretary to the Chief

Section of Economic Entomology

William H. LuckmanN, Ph.D., Entomologist and Head

WILLIS N. Bruce, Ph.D., Entomologist

WAYNE L. HOWE, Ph.D., Entomologist

Stevenson MOORE, III, Ph.D., Entomologiat, Extengion

HOWARo B. PETTY, Ph.D., Entomologist, Extension

J AMES E. APPLEBY, Ph.D., Associate Entomologist

EOWARD J. ARM RRUST. Ph.D., Asaociate Entomologiat

Marcos Kogan, Ph.D.. Associate Entomologiat

JoSEPH V. MADdox. Ph.D., Associate Entomologist

RONALD H. MEYER. Ph.D., Associate Entomologiat

ROBERT D. PAUSCH, Ph.D., Associate Entomologist

RALPH E. SEchriest, Ph.D., Associate Entomologist

JoHN K. Bouseman, M.S., Assistant Entomologiat

GeORGE L. GoofreY, Ph.D., Assistant Entomologist

William G. Ruesink. Ph.D., Assistant Entomalogist

JAMES R. SANBORN, Ph.D., Assiatant Entomologist

Douglas K. SELL, B.S., Assiatant Entomologiat

Clarence E. White, B.S., Asaistant Entomologist

KeUN S. Park, M.S., Agsiatant Chemist

SUe E. Watkins, Superviaory Agaistant

Donald E. Kumlman. Ph.D., Assiatant Professor, Extension

Roscoe Ranoell. Ph.D., Assiatant Profeasor, Extension

TrM CoOLey, M.A., Assigtant Specialist, Extension

JoHN F. WALT, M.S., Assistant Specialist, Extenaion

JEAN G. WILSON, B.A., Supervisor?. Assistant

NATALIE EKL B.A.. Regearch Aseistant

StePHeN K. EVRaro, B.S., Research Assistant

RAYMOND A. KoTEK, M.Mus., Research Assistant

MARTHA P. MiLleR. M.S., Research Asaistant

BARBARA E. PETERSON, B.S., Research Assistant

AN NEMARIE REOBORG, B.S., Rescarch Assistant

KetURA R ReINnolo, M.S., Regcarch Assigtant

Nancy Tsung, M.S., Rescareh Assistant

STEPHEN ROBERTS, B.S., Junior Profesional Scientist

JoHN T. SHAw, B.S., Junior Professional Scientist

DENISE A. CoPE, B.S., Technical Aasistant

LOWELL DAVIS, Technical Assiatant

LU-PING KAN, M.S. Technical Asgistant

MaRy Kathry McClendon, B.S., Technical Assiatant

Cinng-chieH YU, Ph.D., Technical Assiatant

Section of Botany and Plant Pathology

J. Ceoric Carter, Ph.D., Plant Pathologiet and Head ROBERT A. EVERS, Ph.D., Botaniat

Junius L. Forsere, Ph.D., Plant Pathologiat

EUGENe B. HIMELICK, Ph.D., Plant Pathologist

R. DAN Neely, Ph.D., Plant Pathologist

D. F. Schoenewerss, Ph.D., Plant Pathologiat

J. Leland Crane, Ph.D., Associate Mycologist

Walter Hartstirn. Ph.D., Asaistant Plant Pathologigt

Betry S. Nelson, Junior Professional Scientiat

Gene E. ReID, Technicul Assiatant

Section of Aquatic Biology

George W. Bennetr, Ph.D., Aquatic Biologist and

Dead HoMer Buck, Ph.D., Aquatic Biologiat

R. Weloon LARIMORE, Ph.D., Aquatic Biologiat

Robert C. Hiltibran, Ph.D., Biochemist

William F. Chiloers, Ph.D., Associate Aquatic Biologiat

Donald F. Hansen, Ph.D., Agsociate Aquatic Biologist

Richaro E. Sparks, Ph.D., Asoistant Aquatic Biologiat

Arnolo Gnilk a, Ph.D., Junior Profeesional Scientiat RICHARD J. BAUR, M.S., Reaearch Assistant

DenNis L. Doolex, Technical Assiatant
LINDA KLIPPERT, B.S., Technical Aesistant MARY Frances MARTiN, Technical Aseistant

KENNETH R. WALKER, Technical Aseistant

C. Russell Rose, Field Asaistant

Section of Faunistic Surveys and

Insect Indentification

Philip W. Sмith, Ph.D., Taxonomiat and Head

WALLACE E. LABERge. Ph.D., Taxonomist

MulToN W. SANDERSON, Ph.D., Taxonomist

LEWIS J. StanNaro, JR., Ph.D., Taxonomist

LARRY M. PACE, Ph.D., Assistant Taxonomist

JoHN D. UNzICKER, Ph.D., Assistant Taxonomist

DonAld W. WebB, M.S., Assistant Taxonomiet

BERNICE P. SweEney, Junior Professional Soientiat

\section{Section of Wildlife Research}

Glen C. Sanderson. Ph.D., Wildlife Specialist and Head

Frank C. Bellnose, B.S., Wildlife Specialist

RICHARo R. GraBER, Ph.D., Wildlife Specialist

Harold C. Hanson, Ph.D., Wildlife Specialiat

RONAld F. LABISYY, Ph.D., Wildlife Specialiot

WILLIAM L. A NDERSON, M.A., Aesociate Wildlife Specialist

W. W. Cochran, JR., B.S., Ageociate Wildlife Specialist

WillinM R. EDWaros, M.S., Associate Wildlife Specialist

JACK A. Ellis, M.S., Associate Wildlife Specialiet

Charles M. Nixon, M.S., Associate Wildlife Specialist

Kenneth E. SMith, Ph.D., Associate Chemist

ROBERT E. GREENBERG, M.S., Astatant Wildlife Specialist

G. Blair Joselyn, M.S., Aesistant Wildlife Specialist

DAvio R. VANCE, M.S., Asgistant Wildlife Specialiat

RONALD L. Westemeier, M.S., Aeeistant Wildlife Specialist

RoNalo E. DuzaN, Junior Professional Scientiat

HELEN C. Schultz, M.A., Technical Assistant

Eleanore Wilson, Technical Asistant

ROBERT D. CROMPTON, Field Assistant

James W. Seets, Laboratory Assistant

Section of Administrative Services

Robert O. Watson, B.S., Adminiatrator and Head

Supporting Services

VERNON F. BILLMAN, Maintenance Supervisor

WILMA G. DILlmaN, Property Control and Truat Accounts

ROBERT O. ElL1S, Assistant for Operations

LLOYo E. HUFFMAN, Stockroom Manager

J. WILLIAM LUSK, Mailing and Distribution Services MelviN E. SchWARTz, Financial Records

J AMES E. SERGENT. Greenhouse Superintendent

\section{Publications and Public Relations}

OWEN F. GLIssenoorf, M.S., Technical Editor

RoBERT M. ZEW AOSKI, M.S., Associate Technical Editor

Shirley McClellan, Agsistant Technical Editor

LLOYD LEMERE, Tcchnical lllustrator

WiLmer D. ZeHr, Technical Photographer

\section{Technicol Librory}

Doris F, Dooos, M.S.L.S., Technical Librarian

Doris L. SUblette, M.S.L.S., Aseistant Technical Librarian

CONSULTANTS AND RESEARCH AFFILIATES: Systematic ENTOMOLOGY, RODERICK R. IRWIN, Chicago, llinois; Wilolife Research, WILlaro D. Klimstra, Ph.D., Professor of Zoology and Director of Cooperative Wildlife Research, Southern Illinois University: PARAsitologY. NORMAN D. LEviNe, Ph.D., Professor of Veterinary Parasitology. Veterinary Research, and Zoology and Director of the Center for Human Ecology, University of Illinoia; Entomology, ROBERT L. METCALF, Ph.D., Profeseor of Zoology and of Entomology and Head of the Department of Zoology. University of illinois; and GILBERT P. WALDBAUER, Ph.D., Profeseor of Entomology, Univereity of llinois: STATISTICS, HORACE W. NORTON, Ph.D., Profeseor of Statistical Design and Analysis, Iniversity of llinois. 


\section{CONTENTS}

ACKNOWLEDGMNTS $\ldots \ldots \ldots \ldots \ldots \ldots \ldots \ldots \ldots \ldots \ldots \ldots \ldots \ldots \ldots \ldots \ldots \ldots \ldots \ldots$

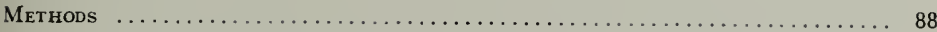

Feeding Trial I: Juvenile Hens $\ldots \ldots \ldots \ldots \ldots \ldots \ldots \ldots \ldots \ldots \ldots \ldots \ldots \ldots$

Feeding Trial II: Adult Hens $\ldots \ldots \ldots \ldots \ldots \ldots \ldots \ldots \ldots \ldots \ldots \ldots \ldots$

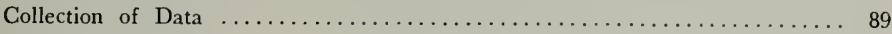

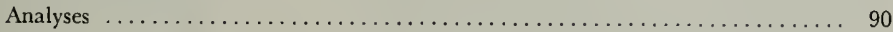

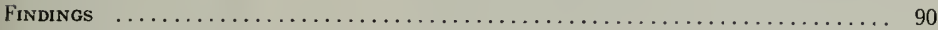

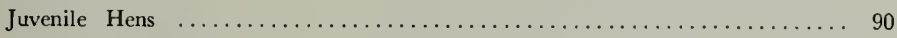

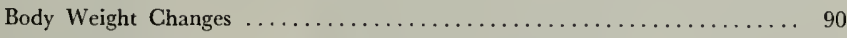

Food Consumption $\ldots \ldots \ldots \ldots \ldots \ldots \ldots \ldots \ldots \ldots \ldots \ldots \ldots \ldots \ldots \ldots \ldots$

Digestibility Coefficients $\ldots \ldots \ldots \ldots \ldots \ldots \ldots \ldots \ldots \ldots \ldots \ldots \ldots \ldots \ldots \ldots$

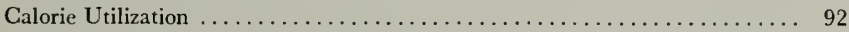

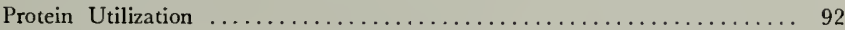

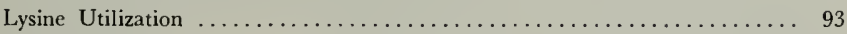

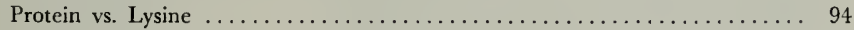

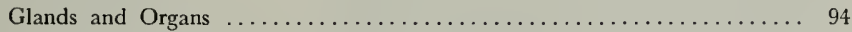

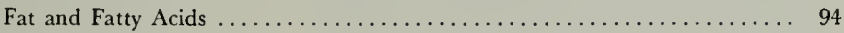

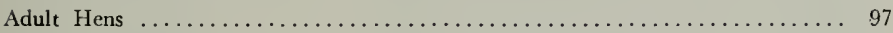

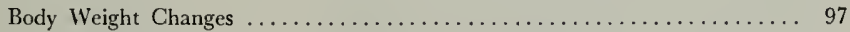

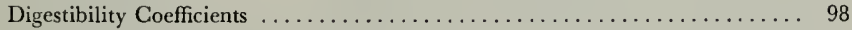

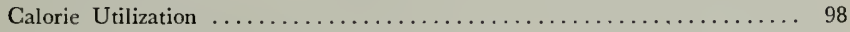

Protein Utilization $\ldots \ldots \ldots \ldots \ldots \ldots \ldots \ldots \ldots \ldots \ldots \ldots \ldots \ldots \ldots \ldots \ldots$

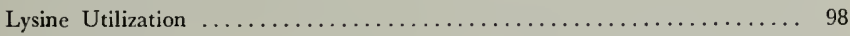

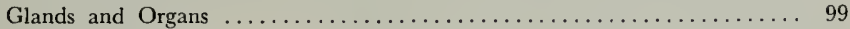

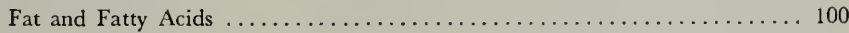

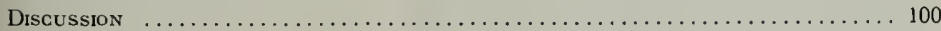

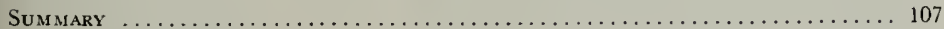

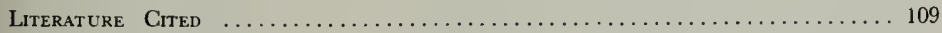

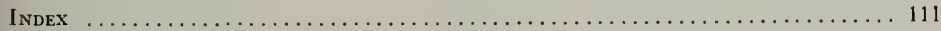

This report is printed by authority of the State of Illinois, IRS Ch. 127, Par. 58.12. It is a contribution from the Section of Wildlife Research of the Illinois Natural History Survey.

(50378-5M-7-73) 


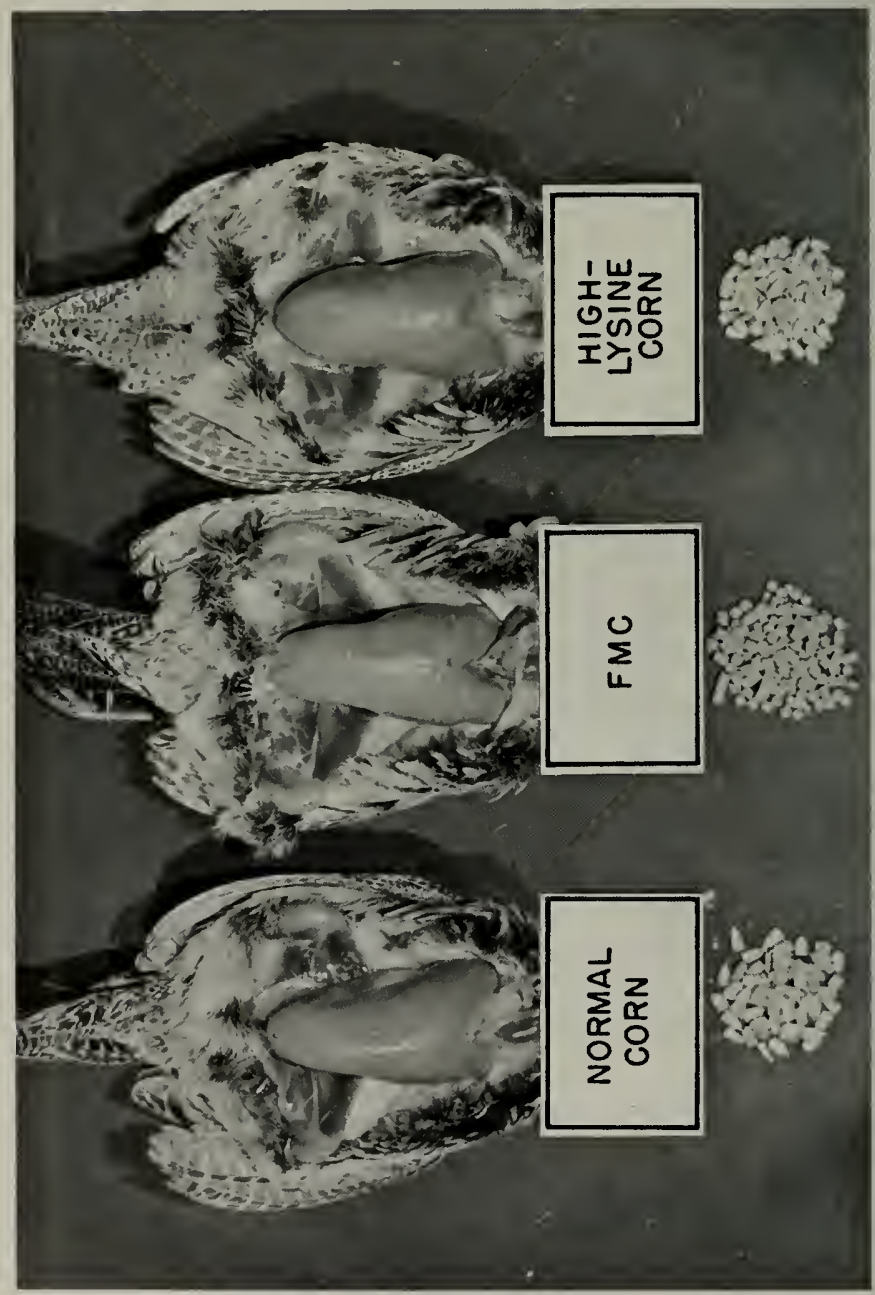

ํํㄹ 인

\& 은 동

동

들

든

ํㅗํ

铰

든

든

믈 定是

은 농

\&

E ฏ

다

훙음

-

E

을 중+

음

ㄷำ

응 묻

$\geqslant \stackrel{0}{2}$

는

놇 ํㅗㄴ

믈

\&

$\simeq \frac{2}{3} 0$

요

으응

듬.

도 훙

- 5

흔

\ั

뭉

$\div$ 든

등

응

훔 으은

동

궁

용

$1 \cdot \frac{5}{x}$

نㅎํ

高 n

능

ㅎํㄴ

은

ज施

运就 


\section{Nutritional Responses of Pheasants \\ to Corn, with Special Reference \\ to High-Lysine Corn}

\section{Ronald F. Labisky William L. Anderson}

IN LATE 1963, Purdue University scientists discovered, by amino acid analysis, that the endosperm of maize (Zea may's) kernels homozygous for the opaque-2 mutant contained about 70 percent more lysine than the endosperms of kernels of normal hybrids (Mertz et al. 1964; Mertz 1966:12). The endosperm of opaque -2 also contained greater amounts of tryptophan than that of normal corn (Pickett 1966:19).

Lysine and trytoplian are among those amino acids that are dietary essentials for protein syntlesis in many animals, including man. The proteins in endosperm of normal corn are of low biological quality. Thus the opaque-2 mutant, which alters the amino acid composition (particularly that of lysine, tryptophan, and leucine) of the maize endosperm, has offered the potential of a type of corn having exceptional nutritional values. The superior nutritional benefits of this modified-protein corn (hereinafter (ermed high-lysine corn) for growth have already been demonstrated in feeding experiments with rats (Mertz et al. 1965; Mertz 1966), swine (Pickett 1966; Jensen et al. 1967). chicks (Rogler 1966 and turkeys (Adams \& Rogler 1970).

The nutritional potential of high-lysine corn has led to predictions that this corn may replace a substantial acreage of normal-corn hybrids produced in the Corn Belt during the 1970's. The estimated acreage of high-lysine corn planted in the United States in 1972 was $80,000-100,000$ acres (D. E. Alexander, University of Illinois, personal communication, January 12, 1973). Inasmuch as corn is important in the diet of many wild animals, the widespread use of ligh- lysine corn offers a potential nutritional benefit to wild birds and mammals.

Corn figures more prominently in the diet of midwestern pheasants, particularly in fall and winter, than it does for most wildlife species (Korschgen 1964: 170,173 ). To illustrate, during fall and winter, corn constitutes at least 80 percent (by weight) of the total food intake by pheasants in thriving populations in eastcentral Illinois (Anderson \& Stewart 1969:261; R. F. Labisky, unpublished data). Yet despite the importance of corn to pheasants, little is known of its nutritional attributes for growth, maintenance, or reproduction. Furthermore, juvenile hens, in contrast to adult heus, suffer a disproportionately ligh rate of nonhunting mortality between fall and winter in Illinois (R. F. Labisky, unpublished data). That the onset of this ınortality among juvenile hens coincides with that time of the year at which waste corn from the harvest suddenly becomes abundantly available suggests a potential causal link between unbalanced nutrition and mortality. Hence the objectives of this study were to ascertain the physiological responses of juvenile hen pheasants in fall, and of adult hen pheasants in late winter and early spring, to exclusive diets of both normal corn and high-lysine corn.

\section{ACKNOWLEDGMENTS}

Acknowledgment is due the following members of the Department of Agronomy, Lniversity of Illinois. Dr. D. E. Alexander supplied the corns, provided their lysine and fatty acid profiles, and offered advice on various aspects of the 
study. Dr. T. R. Peck and G. G. Stone offered laboratory facilities for, and materially aided in, the analyses of pheasant excreta for nitrogen. Dr. I. de la Roche analyzed the fat samples for determination of fatty acids. Dr. C. M. Wilson analyzed the commercial ration for amino acids.

Dr. B. G. Harmon, Department of Animal Science, University of Illinois, supervised the analyses of pheasant excreta for lysine.

Dr. G. C. Sanderson, Illinois Natural History Survey, offered editorial suggestions during preparation of the paper, and $O$. F. Glissendorf edited the final manuscript. D. R. Vance and J. E. McClendon of the Survey assisted in various aspects of the experiment.

Special thanks are due Drs. Alexander and Harmon, and Dr. J. E. Savage, Department of Poultry Science, University of Missouri, for critically reviewing the manuscript.

\section{METHODS}

\section{FEEDING TRIAL I: JUVENILE HENS}

The 21 juvenile hens used in the experiment were obtained from the Illinois State Game Farm, Yorkville, in 1966. These hens, which had hatched on June 20, were transported to Urbana on September 13. The hens were held in two wire-bottomed $3.0 \times 3.9 \times 1.8$-meter pens and fed a commercial flight and maintenance chow (FMC) until October 3 when they were individually placed, by random assortment, in $70 \times 60 \times 34-\mathrm{cm}$ cages. The cages had thin-walled fiberglass sides, top, bottom, and rear, which prevented sight contact between birds. The birds were fed a diet of two-thirds FMC and one-third normal corn (whole kernels) for the period October 3-14 to acquaint them with corn, and then an exclusive diet of FMC for the period October 15-20.

Inasmuch as 19 of the 21 hens posted gains in body weight between Octo- ber 10 and October 20, the feeding trial was begun on the latter date. Three groups of 7 hens each were randomly selected to be fed exclusive, unrestricted diets of FMC, normal hybrid corn (Pioneer 3306), or high-lysine corn (Table 1), and water ad libitum. The FMC was pressed into corn-sized pellets for the fceding trials (see Frontispiece). The experiment was terminated 8 weeks later, December 15. One hen from the group of hens fed normal corn died from an injury during the trial.

\section{FEEDING TRIAL II: ADULT HENS}

The 12 adult hens, 3 and 4 years old, used in the feeding trial were also of game-farm origin. These hens had been transported to Urbana as juveniles, and subsequently maintained in wire-bottomed outdoor pens, similar to those used to house the juveniles. On February 7, 1967 , these hens were individually placed, by random assortment, in the same cages in which the juveniles of Trial I had been held. They had been fed an introductory diet of one-half FMC, onefourth normal corn, and one-fourth highlysine corn for the period February 1-7. Because of their quick acceptance of corn, they were returned to an exclusive FMC diet on February 8.

All 12 hens posted gains in body weight during the interval of February 27-March 6 ; therefore, the feeding trial was begun on the latter date. Six hens were offered a diet of normal corn and six hens a diet of high-lysine corn (Table 1); both groups had unrestricted access to water. The food intake by adult hens was restricted to $200 \mathrm{~g}$ of corn per bird per week. The corn was provided in two $100-\mathrm{g}$ lots, on the first and fourth days of each week. This limited offering of corn was judged to be about 60 percent of a normal weekly intake, and was intended to simulate the estimated potential food intake of wild hens subjected to the rigors of late winter in Illinois. The experiment was terminated after 7 weeks, on April 24. 
Toble 1.- Meon concentrations of calories, crude protein, lysine in protein, ond selected minerols in diets of a commercial flight and maintenonce chow (FMC), of normol corn, ond of high-lysine corn thot were fed to hen pheosonts in 1966 ond 1967.

\begin{tabular}{|c|c|c|c|}
\hline & \multicolumn{3}{|c|}{ Diets } \\
\hline & FMC & $\begin{array}{c}\text { Nurmal Corn: } \\
\text { Pioneer } 3306\end{array}$ & $\begin{array}{l}\text { High-Lysine Corn } \\
\text { Opaque-2 } \\
\text { Synthetic } A_{0}\end{array}$ \\
\hline$\overline{\text { Calories per } \mathrm{g}^{a}}$ & $4,278.9 \pm 4.4^{b}$ & $4,651.6 \pm 99.1$ & $4,544.0 \pm 6.1$ \\
\hline $\begin{array}{l}\text { Percentage crude } \\
\text { protein }^{\circ}\end{array}$ & $22.8 \pm 0.03$ & $12.0 \pm 0.1^{a}$ & $11.7 \pm 0.1$ \\
\hline $\begin{array}{l}\text { Percentage lysine } \\
\text { in protein }\end{array}$ & 4.9 & $3.2^{d}$ & 4.7 \\
\hline Percentage fiber & $\leq 12.0$ & 2.0 & 2.0 \\
\hline $\begin{array}{l}\text { Percentage saturated: } \\
\text { unsaturated fatty acids }\end{array}$ & $g$ & $14: 86$ & $19: 81$ \\
\hline $\begin{array}{l}\text { ppm of major elements } \\
\text { calcium } \\
\text { magnesium } \\
\text { sodium } \\
\text { potassium } \\
\text { phosphorus } \\
\end{array}$ & $\begin{aligned} 14,443 & \pm 1,469 \\
1,833 & \pm 24 \\
2,785 & \pm 49 \\
7,997 & \pm 159 \\
5,327 & \pm 220\end{aligned}$ & $\begin{aligned} 41 & \pm 3 \\
1,166 & \pm 48 \\
204 & \pm 9 \\
3,249 & \pm 138 \\
2,183 & \pm 250\end{aligned}$ & $\begin{aligned} & 38 \pm 1 \\
& 972 \pm 37 \\
& 195 \pm 4 \\
& 3,924 \pm 184 \\
& 2,264 \pm 202 \\
&\end{aligned}$ \\
\hline
\end{tabular}

a Caloric contents of the rations differed significantly $\left(F=11.18_{2, \mathrm{e}} ; \mathbf{P}<0.05\right)$; application of Duncan's multiple range test indicated that the caloric content of both corns differed from FAtC but not from each other.

S Standard crrors.

c Crude protein compositions of the rations differed significantly $\left(\mathrm{F}=989.66_{2,22} ; \mathbf{P}<0.05\right)$; application of Duncan's multiple range test indicated that the caloric content of both corns differed from FMC, but not from each other.

d This particular hybrid contains slightly greater concentrations of protein and of lysine than most normal corn hybrids. The average normal corn hybrid contains about 10.5 percent protein, of which 2.8 percent is lysine.

"Lysine content is for defatted samples.

The principal fatty acids in the corns are unsaturated: oleic and linoleic. The normal and high-lysine corns contamed, respectively, 34 and 22 percent oleic, and 52 and 58 percent linoleic acid.

- Data are not available.

\section{COLLECTION OF DATA}

Body weights of the hens were recorded at the onset of the feeding trials and at weekly intervals thereafter. Correspondingly, the amount of food consumed by each hen during each week of the feeding trial was measured to the nearest gram. All food consumption was converted to a dry weight standard. The total excreta was collected for each juvenile hen for Weeks $t, 5,6,7$, and 8 (final) and for each adult hen for Weeks 5 and 7 (final).

After the final body weight of the hens had been recorded, each hen was placed in an inverted position and decapitated. All birds were then dissected. The following muscles, fat deposits, organs, and glands were excised from both juvenile and adult hens, and weighed: muscles of right half of the sternum (pectoralis thor- acia, ventral head of the supracoracoideus, and coracobrachialis-nomenclature as used by Hudson \& Lanzillotti 196+: 13-15); fat strip and visceral fat (as described by Breitenbach \& Meyer 1959: 1017); liver; thyroids; parathyroids; and adrenals. The heart, pancreas, gizzard, kidneys, spleen, and thymuses from juvenile hens were also excised and weighed, as were the ovary, oviduct, and largest ovim from the adult hens. The organs and glands, after being freed of extraneous material, were blotted carefully with paper toweling to remove excess blood and moisture prior to being weighed. The heart and liver were opened and blood clots therein removed; the gall bladder was excised from the liver. The contents, but not the lining, were removed from the gizzard before the latter was weighed. The weights 
recorded for kidneys and endocrine glands are for paired (right and left) measurements.

\section{ANALYSES}

Each sample of food and excreta was oven-dried at $60^{\circ} \mathrm{C}$ for 142 hours, finely ground, and then sealed in a sterile plastic bag for subsequent determination of nitrogen (crude protein), lysine, and caloric content.

Nitrogen content of foods and excreta was determined by $\mathrm{Kjeldahl}$ procedures; the crude protein content of each item was calculated as nitrogen $\mathrm{x}$ 6.25. Crude protein determinations were made for five samples of each of the three foods, and for single samples of dried excreta from each juvenile hen for each of the last 5 weeks of the 8-week experiment and for each adult hen for Weeks 5 and 7 of the 7-week experiment.

Lysine in the pheasant excreta was measured, following acid hydrolysis under vacuum for 16 hours, by chromatographic analysis (Beckman Amino Acid Analyzer, Model 120). Lysine determinations for excreta were made from composites of the weekly samples for Weeks 4-8 of the 8-week experiment for each juvenile hen, and for Weeks 5 and 7 of the 7-week experiment for each adult hen. The amount of lysine in the foods (defatted) was also measured by chromatographic analysis; approximately 80 percent of the nitrogen in the foods was recovered as amino acids.
Caloric content of foods and excreta was measured by standard caloric-bomb techniques. Calories were measured from three samples of each of the three foods, and from a composite of the five and two weekly collections of excreta from each juvenile and each adult hen pheasant, respectively.

The mineral content of the foods was derived by atomic absorption spectrophotometry (for $\mathrm{Ca}$ and $\mathrm{Mg}$ ), flame spectrophotometry (for $\mathrm{Na}$ and $\mathrm{K}$ ), and colorimetry (for P).

The null hypothesis, in all tests for determination of statistical differences, was accepted or rejected at the 0.05 level of probability.

\section{FINDINGS}

\section{JUVENILE HENS}

\section{Body Weight Changes}

The juvenile hens that were fed exclusive diets of FMC or high-lysine corn posted gains in body weight that averaged 98.4 and $23.4 \mathrm{~g}$, respectively, during the 8-week feeding trial; those fed normal corn suffered losses that averaged $8.7 \mathrm{~g}$ (Table 2). Both groups of hens to which corn was fed exhibited marked declines in body weight during the first week of the feeding trial (Fig. 1). In the final analysis, all of the seven hens fed FMC, five of the seven hens fed high-lysine corn, and three of the six hens fed normal corn gained weight during the

Table 2.-Body weight statistics for juvenile hen pheosonts fed exclusive diets of flight and maintenance chaw (FMC), of normal corn, or at high-lysine corn for an 8-week period, October 20December 15, 1966.

\begin{tabular}{|c|c|c|c|c|}
\hline & \multicolumn{3}{|c|}{$\begin{array}{c}\text { Mean Body Weight }(\mathrm{g}) \text { or Weight Change } \\
\text { for Specified Dict }\end{array}$} & \multirow[b]{2}{*}{$F$ Values(dr) } \\
\hline & $\begin{array}{c}\text { FMC } \\
(\mathrm{n}=7 \text { Hens })\end{array}$ & $\begin{array}{l}\text { Normal Corn } \\
(n=6 \text { Hens })\end{array}$ & $\begin{array}{l}\text { High-Lysine Corn } \\
\text { (n=7 Hens) }\end{array}$ & \\
\hline \multirow{2}{*}{$\begin{array}{l}\text { Initial weight (Oc- } \\
\text { tober } 20) \\
\text { Final weight (De- } \\
\text { cember } 15)\end{array}$} & $711.3 \pm 29.2^{\circ}$ & $742.2 \pm 36.9$ & $752.7 \pm 32.4$ & $0.45_{2,17}$ \\
\hline & $809.7 \pm 29.6$ & $733.5 \pm 35.8$ & $776.1 \pm 39.6$ & $1.13_{2,17}$ \\
\hline Weight change & $+98.4 \pm 7.6$ & $-8.7 \pm 14.7$ & $+23.4 \pm 27.8$ & $4.70_{2,17}$ * \\
\hline
\end{tabular}

* Denotes statistical significance, $\mathbf{P}<0.05$. AIl combinatians of paired means differed significantly. a Standard errors. 


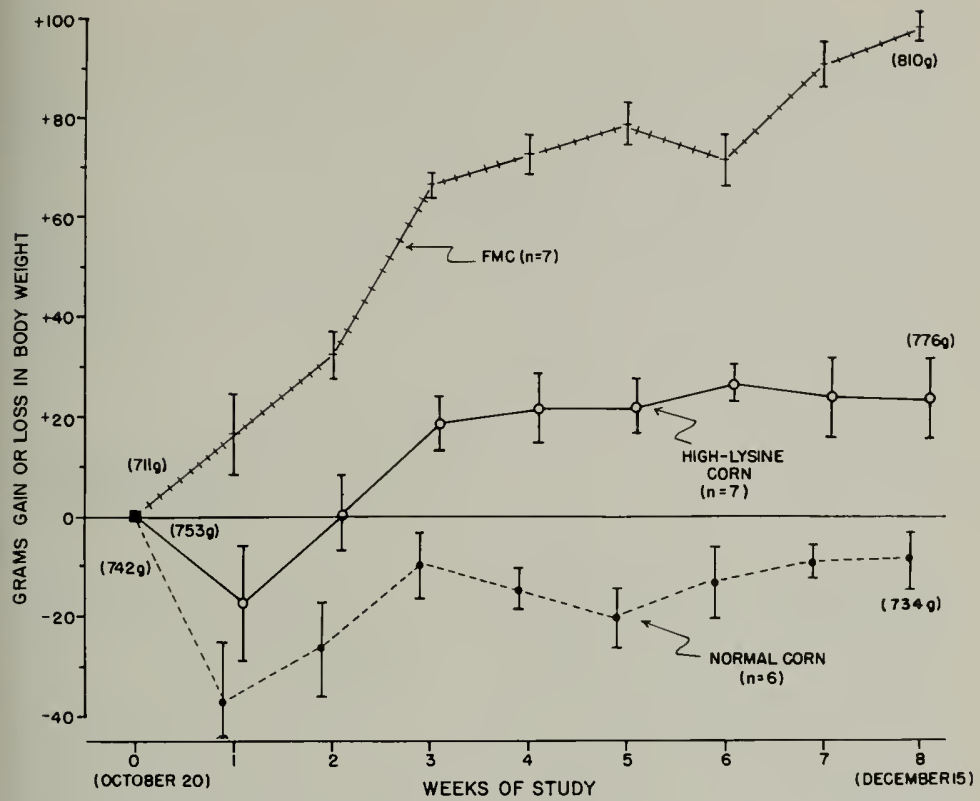

Fig. 1.- Mean change in body weight ( $g$ ) by weekly periods omong juvenile hen pheosants fed exclusive diets of FMC, of normal carn, ar af lysine carn; the vertical lines transecting the means are standard errors. The mean initial ond final body weights for each group ore given at the left and right of the graph, respectively. Statistically significant $(P<0.05 ; 2$ and $19 \mathrm{df})$ weight changes occurred among diets for three of the eight successive weekly periods: initial to $1(F=3.73) ; 2$ to $3(F=3.93)$; and 6 to 7 (F $=3.59)$.

8 weeks. The extremes in weight change among hens on each of the diets were: FMC, +128 and $+59 \mathrm{~g}$; high-lysine corn, +177 and $-88 \mathrm{~g}$; and normal corn, +44 and $-71 \mathrm{~g}$.

\section{Food Consumption}

The three diets, fed ad libitum, were consumed by the juvenile hens in significantly different amounts; the greatest intake was of FMC and the lowest was of normal corn (Table 3). Inasmuch as the caloric, crude protein, and lysine contents of the high-lysine corn were either similar to or greater than those of normal corn (Table 1), thereby discounting compensatory nutritional needs, the greater rate of consumption of high-lysine corn per hen suggested that it may have been more palatable ${ }^{1}$ to pheasants than normal corn. Changes in body weight per $100 \mathrm{~g}$ of food consumed averaged +4.3 , +1.3 , and $-0.5 \mathrm{~g}$ on $\mathrm{FMC}$, high-lysine corn, and normal corn, respectively.

\section{Digestibility Coefficients}

Significant differences in the digestibility coefficients ${ }^{2}$ were exhibited by hens

1 Food intake is often depressed if the animal's diet is deficient in either protein or an indispensable amino acid (see review by Harper, 1967). Therefore, the greater consurnption of high-lysine corn over normal corn by the hens may have reflected its higher lysine content rather than any superiority in palatability.

$$
\begin{aligned}
& \text { 2Digestibility coefficient }= \\
& {\left[1-\left(\frac{\text { Total dry weight of excreta }}{\text { Total dry weight of food consumed }}\right) \times 100\right]}
\end{aligned}
$$


on the different diets (Table 3). Hens fed FMC digested substantially less (59.1 percent) of their ration than did those hens fed either normal corn (82.5 percent) or high-lysine corn (81.2 percent). In contrast to the corns, the comparatively low rate of digestibility of FMC, in part, reflected its higher fiber content. Despite the similarity in the mean digestibility coefficients of the two corns, they were significantly different because of the extremely narrow range of variation in the digestibility of each of the corns by the individual hens.

\section{Calorie Utilization}

Although the total intake of calories by the juvenile hens was significantly greater for those fed FMC than for those fed either normal corn or high-lysine corn, the utilization of the calories by the hens receiving the FMC was markedly less than for those receiving either of the corns; the metabolizability coeffi- cients $^{3}$ were 66.3, 84.8, and 83.3 for FMC, normal corn, and high-lysine corn, respectively (Table 4). Because of this different proportionate utilization of calories, there was no significant difference in the total number of calories utilized per hen for birds on the three diets during the 8-week trial. Juwenile hens obtained $2,837,3,945$, and $3,808 \mathrm{kcal}$ of metabolizable energy per $\mathrm{kg}$ of FMC, normal corn, and high-lysine corn consumed, respectively.

\section{Protein Utilization}

The intake of crude protein by the juvenile hens was significantly different among the birds fed the three diets, being more than twice as great for FMC as for either normal or high-lysine corn ( Table 3 ). The high intake of crude protein by the hens fed FMC reflected not only

\footnotetext{
${ }^{3}$ Metabolizability coefficient $=$

$\left[1-\left(\frac{\text { Total calories in excreta }}{\text { Total calories in food consumed }}\right) \times 100\right]$
}

Table 3.-Comparative cansumptian and utilization of three foads-flight and maintenonce chaw (FMC), normal corn, and high-lysine corn-fed as exclusive diets ta different groups of juvenile hen pheasants far an 8 -week periad, Octaber 20-December 15, 1966. All values are expressed as dry weight.

\begin{tabular}{|c|c|c|c|c|}
\hline & \multicolumn{3}{|c|}{$\begin{array}{l}\text { Mean Value per Hen per Week } \\
\text { for Specified Diet }\end{array}$} & \multirow[b]{2}{*}{$F$ Values(dt) } \\
\hline & $\begin{array}{c}\text { FMC } \\
(\mathrm{n}=7 \text { Hens })\end{array}$ & $\begin{array}{c}\text { Normal Corn } \\
(\mathrm{n}=6 \text { Hens })\end{array}$ & $\begin{array}{c}\text { High-Lysine Corn } \\
(\mathrm{n}=7 \text { Hens })\end{array}$ & \\
\hline $\begin{array}{l}\text { Food consumed }(\mathrm{g}) \\
\text { Crude protein }\end{array}$ & $282.4 \pm 12.9^{a}$ & $205.6 \pm 10.8$ & $234.6 \pm 17.0$ & $65.11_{2,330} *$ \\
\hline consumed $(\mathrm{g})^{b}$ & $64.4 \pm 1.0$ & $24.7 \pm 1.3$ & $27.5 \pm 0.7$ & $888.51_{2,13 \mathrm{6}}$ * \\
\hline Lysine consumed $(\mathrm{g})^{\circ}$ & $3.2 \pm 0.06$ & $0.8 \pm 0.01$ & $1.3 \pm 0.03$ & $2,305.51_{2,130}$ * \\
\hline Excreta $(\mathrm{g})^{d}$ & $115.5 \pm 2.1$ & $36.0 \pm 0.6$ & $44.2 \pm 1.0$ & $716.81_{2,83} *$ \\
\hline $\begin{array}{l}\text { Digestibility } \\
\text { coefficient } \\
\text { (percent) }^{d}\end{array}$ & $59.1 \pm 0.3$ & $82.5 \pm 0.2$ & $81.2 \pm 0.3$ & $2,266.67_{2,53}$ * \\
\hline $\begin{array}{l}\text { Crude protein in } \\
\text { excreta (percent)" }\end{array}$ & $39.3 \pm 1.5$ & $47.9 \pm 0.9$ & $47.2 \pm 0.7$ & $20.92_{2, \mathrm{~ns}}$ * \\
\hline $\begin{array}{l}\text { Crude protein } \\
\text { utilized }(\mathrm{g})^{d}\end{array}$ & $16.2 \pm 1.8$ & $6.5 \pm 0.4$ & $5.7 \pm 0.4$ & $24.24_{2, s 3}$ * \\
\hline$(\text { percent })^{d}$ & $26.0 \pm 2.5$ & $\overline{27.2} \pm 1.6$ & $\overline{21.0 \pm 1.4}$ & $3.11_{2,83}$ \\
\hline $\begin{array}{l}\text { Change in body } \\
\text { weight }(\mathrm{g})\end{array}$ & +12.3 & -1.1 & +2.9 & \\
\hline
\end{tabular}


Table 4.- Comparative consumption and utilization of calories by juvenile hen pheasonts fed exclusive diets of a flight and maintenance chow (FMC), of normal corn, or of high-lysine corn for an 8-week period, Octaber 20-December 15, 1966.

\begin{tabular}{|c|c|c|c|c|}
\hline & \multicolumn{3}{|c|}{$\begin{array}{l}\text { Mean Value per Hen per 8-Week Period } \\
\text { for Specified Diet }\end{array}$} & \multirow[b]{2}{*}{$F$ Values $_{\text {sds }}$} \\
\hline & $\begin{array}{c}\text { FMC } \\
(\mathrm{n}=7 \text { Hens })\end{array}$ & $\begin{array}{c}\text { Normal Corn } \\
(\mathrm{n}=6 \text { Hens) }\end{array}$ & $\begin{array}{c}\text { High-Lysine Corn } \\
(\mathrm{n}=7 \text { hens })\end{array}$ & \\
\hline $\begin{array}{l}\text { Calories consumed } \\
\text { (kcal) }\end{array}$ & $9,688 \pm 244^{a}$ & $\underline{7,501 \pm 179}$ & $8,357 \pm 542$ & $6.76_{2,17}{ }^{*}$ \\
\hline $\begin{array}{l}\text { Calories per } \mathrm{g} \\
\text { excreta }^{8}\end{array}$ & $3,359 \pm 19$ & $3,892 \pm 23$ & $3,888 \pm 30$ & $156.99_{2,17} *$ \\
\hline $\begin{array}{l}\text { Calories utilized } \\
(\text { kcal })^{\circ} \\
(\text { percent })^{\circ}\end{array}$ & $\begin{aligned} 6,409 & \pm 147 \\
66.3 & \pm 0.4\end{aligned}$ & $\begin{aligned} 6,486 & \pm 176 \\
84.8 & \pm 0.3\end{aligned}$ & $\begin{aligned} 6,959 & \pm 477 \\
83.3 & \pm 0.2\end{aligned}$ & $\begin{array}{c}0.91_{2,17} \\
1,005.63_{2,17}^{*}\end{array}$ \\
\hline
\end{tabular}

* Denotes statistical significance, $P<0.05$. Those means underscored by the same line are not significantly different.

a Prandard errors. for each hen.

Caloric values for Weeks 48 .

their high rate of consumption of the ration but also the ration's high protein content (22.8 percent). Whereas the proportionate utilization of the crude protein consumed by the hens did not differ significantly among diets (Table 3 ), those hens fed FMC utilized nearly $2 \frac{1}{2}$ times more crude protein than did hens fed either of the corns. Changes in body weight of the juvenile hens were related directly $(r=0.56,18 \mathrm{df} ; P<0.05)$ to the amount of crude protein utilized.

\section{Lysine Utilization}

The intake of lysine by the juvenile hens also differed significantly among the three diets; the hens fed FMC consumed about $21 / 2$ and 4 times as much as those hens fed lysine corn and normal corn, respectively (Table 5 ). The proportionate utilization of lysine, however, was greatest for hens fed high-lysine corn (99.2 percent), and differed significantly from that for hens fed either normal corn (88.4 percent) or FMC (85.6 percent). The total amount of lysine utilized per hen during the 8-week feeding trial differed significantly among the diets, averaging $21.6 \mathrm{~g}$ on FMC, $10.2 \mathrm{~g}$ on highly sine corn, and $5.6 \mathrm{~g}$ on normal corn. The response in body weight of the juvenile hens was strongly dependent $(r=$

Table 5.-Comparative consumption and utilization of lysine by juvenile hen pheosonts fed exclusive diets of a flight and maintenance chow (FMC), of normal corn, or of high-lysine corn for an 8 -week period, October 20-December 15, 1966.

\begin{tabular}{|c|c|c|c|c|}
\hline & \multicolumn{3}{|c|}{$\begin{array}{c}\text { Mean Value per Hen per 8-Week Period } \\
\text { for Specified Diet }\end{array}$} & \multirow[b]{2}{*}{$F$ Values(ds) } \\
\hline & $\begin{array}{c}\text { FMr. } \\
\langle\mathrm{n}=7 \text { Hens })\end{array}$ & $\begin{array}{l}\text { Normal Cuin } \\
(n=6 \text { Hens })\end{array}$ & $\begin{array}{l}\text { High-Lysine Corn } \\
\text { ( } \mathrm{n}=7 \text { Hens })\end{array}$ & \\
\hline ysine consumed (g) & $25.2 \pm 0.6^{a}$ & $6.3 \pm 0.2$ & $10.3 \pm 0.7$ & $314.24_{2,17^{*}}$ \\
\hline $\begin{array}{l}\text { Gysine utilized } \\
\qquad(\mathrm{g})^{\mathrm{b}}\end{array}$ & $21.6 \pm 0.4$ & $5.6 \pm 0.1$ & $10.2 \pm 0.7$ & $311.67_{2,17} *$ \\
\hline$(\text { percent })^{e}$ & $85.6 \pm 1.5$ & $88.4 \pm 1.0$ & $99.2 \pm 0.1$ & $51.24_{2.17} *$ \\
\hline
\end{tabular}

* Denotes statistical significance, $\mathrm{P}<0.05$. Those means underscored by the same line are not significantly different.

a Standard errors.

Product of the 8-week consumption of lysine and the 5-week (Weeks 4-8) percentage utilization of lysine for each hen.

c Utilization values for Weeks 4-8. 
$0.73,18 \mathrm{df} ; P<0.05)$ on the amount of lysine utilized.

\section{Protein vs. Lysine}

Significant differences existed in the quantitative utilization of both crude protein and lysine by the juvenile hens on the three diets, which warranted a more definitive examination of the contribution of these two variables to the growth and maturation processes of pheasants. Hence, the influences of the quantitative utilization of crude protein and of lysine, irrespective of diets, on the corresponding gain or loss in body weight of the juvenile hens were measured by multiple regression analysis (Table 6). This analysis revealed, as previously demonstrated, that both the amount of crude protein utilized and the amount of lysine utilized, when considered separately, significantly influenced the body weights of juvenile hens in autumn. After accounting for crude protein, the amount of lysine utilized made a significant contribution to regression; however, the interjection of crude protein after accounting for lysine did not reveal a significant contribution to regression. Thus although the body weight of juvenile hen pheasants was significantly dependent on the utilized amounts of both crude protein and lysine when the two variables were considered singly, it was significantly dependent only on the utilized amount of lysine when the two variables were considered together (Table 6).

\section{Glands and Organs}

The mean weights of gizzards, parathyroid glands, adrenal glands, and kidneys differed significantly among the hens fed diets of FMC, normal corn, or highlysine corn (Table 7). These differences, except in the case of kidneys, also were evident when the weights of the glands or organs were expressed as percentages of body weight.

The size of the adrenal glands, when expressed as an index percentage of body weight, was inversely correlated with the gain (or loss) in body weight of the juvenile hens (Fig. 2), and thus adrenal size was generally greatest for hens fed normal corn, intermediate for those fed highlysine corn, and least for those fed FMG.

\section{Fat and Fatty Acids}

Although the deposits of fat, whether strip or visceral, did not differ statistically among the juvenile hens fed the three diets, they were greatest for juvenile hens fed high-lysine corn, intermediate for those fed FMC, and least for those fed normal corn (Table 7). The accumulations of fat by hens fed high-lysine corn averaged nearly three times greater than accumulations of fat by hens fed normal corn.

The distribution of the fatty acids con-

Table 6.-Analysis of vorionce, as derived from multiple lineor regression analysis, of the effects of the utilized amounts of crude protein ( 9 ) and lysine (g) on the gains or losses in body weight $(\mathrm{g})$ of juvenile hen pheosants in outumn. The null hypothesis is thot the contribution to regression from $X_{1}$ is zero, where $i=1$ (crude protein), 2 (lysine).

\begin{tabular}{lcccc}
\hline \hline Source & DF & SS & MS & \multicolumn{1}{c}{$F$} \\
\hline $\mathrm{X}_{1}$ regression & 1 & 27,974 & 27,974 & $10.73^{*}$ \\
$\mathrm{X}_{2}$ regression $\mid \mathrm{X}_{1}$ & 1 & 16,515 & 16,515 & $6.33^{*}$ \\
Residual & 17 & 44,318 & 2,607 & \\
Total & 19 & 88,807 & & $17.03^{*}$ \\
$\mathrm{X}_{2}$ regression & 1 & 44,392 & 44,392 & 0.04 \\
$\mathrm{X}_{1}$ regression $\mid \mathrm{X}_{2}$ & 1 & 97 & 97 & \\
Residual & 17 & 44,318 & 2,607 & \\
Total & 19 & 88,807 & & \\
\hline
\end{tabular}

* Denotes statistical significance, $\mathrm{P}<0.05$. 
July, 1973 Labisky \& Anderson: Nutritional Responses of Pheasants

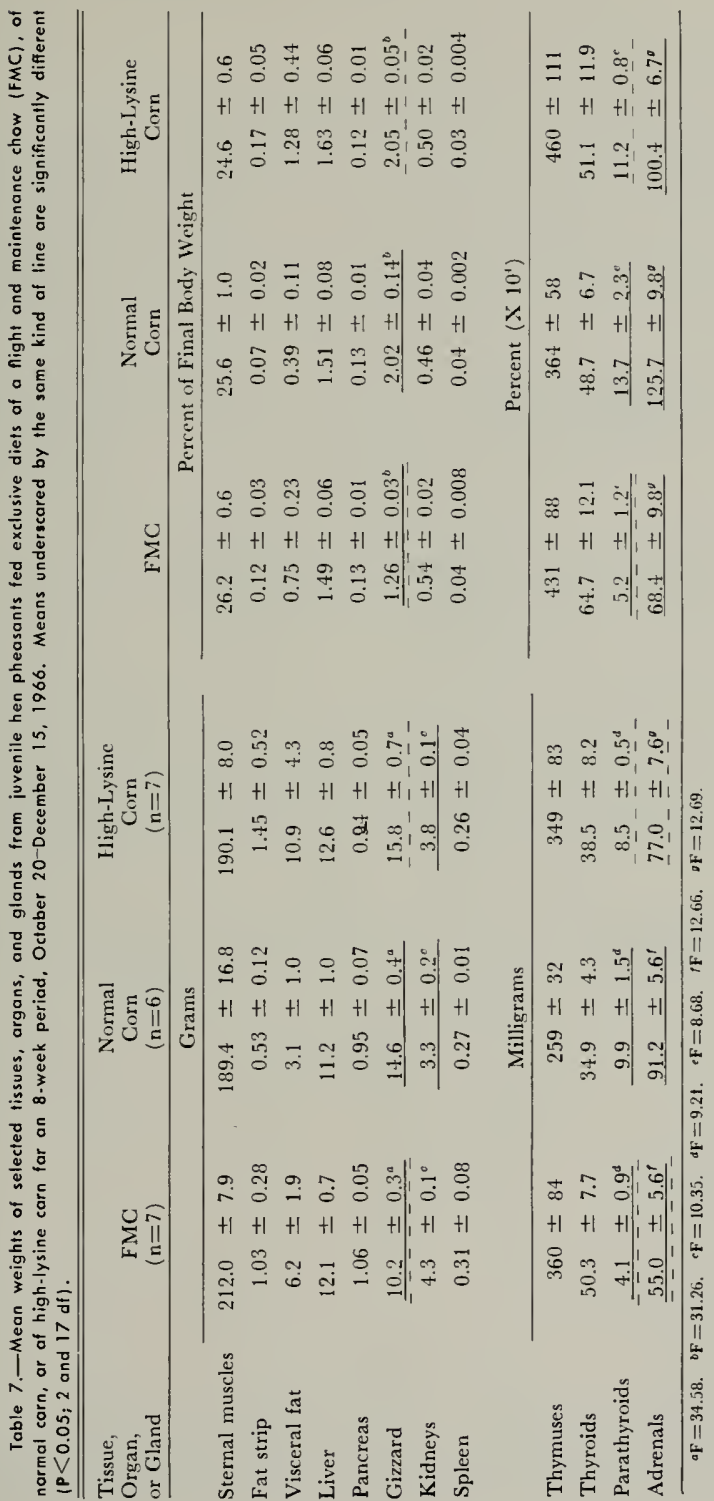




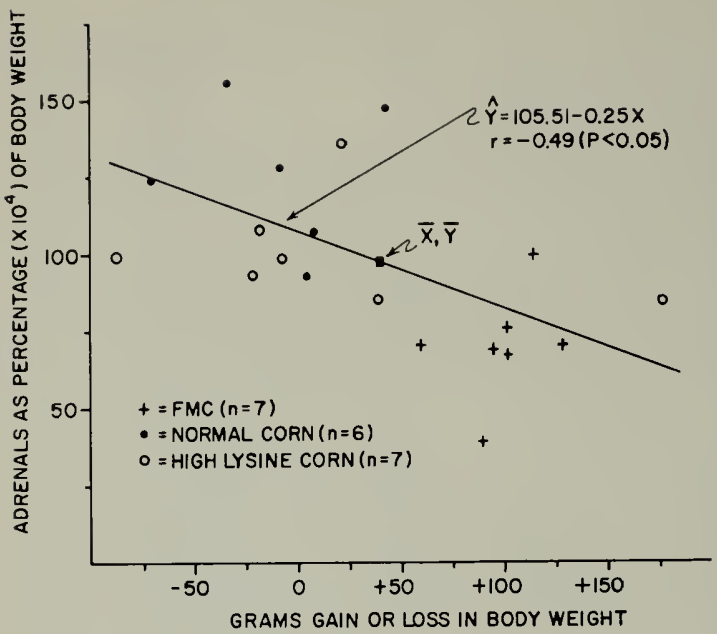

Fig. 2. - Relationship, os indicated by linear carrelatian, between gain or loss in body weight $(\mathrm{g})$ and the carresponding size of adrenal glands (expressed as $10^{4}$ percentage of final body weight) for juvenile hen pheasants fed exclusive diets of either FMC, normal corn, or high-lysine corn far the total 8 week feeding trial, October 20-December 15 , 1966.

tained in the visceral fat of juveniles was almost the same for birds on diets of normal corn and high-lysine corn; the ratio of saturated to unsaturated fatty acids in the visceral fat was about $27: 73$ for both corn diets (Table 8 ). The vis- ceral fat of juvenile hens fed FMC contained a higher proportion of saturated fatty acids than did fat from hens fed either of the two corns, the principal differences being in the distribution of palmitic, stearic, and linoleic acids.

Table 8.- Percentage distribution of fatty acids contained in the visceral fat of juvenile and odult hens fed exclusive diets of night and maintenance chaw (FMC), of normal carn, or of high-lysine carn. Values represent the mean of twa replicated compasite samples of visceral fat from hens in each agediet graup.

\begin{tabular}{|c|c|c|c|c|c|}
\hline \multirow{2}{*}{$\begin{array}{l}\text { Fatty Acids } \\
\text { in } \\
\text { Visceral Fat }\end{array}$} & \multicolumn{3}{|c|}{ Juvenile Hens } & \multicolumn{2}{|c|}{ Adult Hens } \\
\hline & FMC & $\begin{array}{c}\text { Normal } \\
\text { Corn }\end{array}$ & $\begin{array}{l}\text { High-Lysine } \\
\text { Corn }\end{array}$ & $\begin{array}{c}\text { Normal } \\
\text { Corn }\end{array}$ & $\begin{array}{c}\text { High-Lysine } \\
\text { Corn }\end{array}$ \\
\hline Saturated acids & & & & & \\
\hline Lauric $(12: 0)^{n}$ & 1.0 & 0.9 & 0.6 & 0.8 & 0.5 \\
\hline Myristic $(14: 0)$ & 0.4 & 0.3 & 0.2 & 0.3 & 0.2 \\
\hline Palmitic $(16: 0)$ & 24.2 & 21.0 & 21.4 & 20.5 & 16.6 \\
\hline Stcaric $(18: 0)$ & 8.2 & 4.8 & 5.2 & 6.2 & 5.8 \\
\hline Subtotal & 33.8 & 27.0 & 27.4 & 27.8 & 23.1 \\
\hline Unsaturated acids & & & & & \\
\hline Palınitoleic $(16: 1)$ & 7.4 & 7.4 & 6.6 & 7.7 & 6.0 \\
\hline Oleic $(18: 1)$ & 37.8 & 37.6 & 39.6 & 39.1 & 41.8 \\
\hline Linoleic $(18: 2)$ & 17.8 & 27.9 & 25.8 & 22.4 & 28.3 \\
\hline Linolenic $(18: 3)$ & 1.0 & b & b & 3.0 & b \\
\hline Arachidonic $(20: 4)$ & 2.2 & $b$ & 0.7 & 0.1 & 0.5 \\
\hline Subtotal & 66.2 & 72.9 & 72.7 & 72.3 & 76.6 \\
\hline Total (percentage) & 100.0 & 99.9 & 100.1 & 100.1 & 99.7 \\
\hline
\end{tabular}

a the numbers preceding and following the colons represent the number of carbon atoms and the number of bonds, respectively.

$b$ Not isolated in analysis. 


\section{ADULT HENS}

\section{Body Weight Changes}

Adult hen pheasants that were fed either normal corn or high-lysine corn at the restricted rate of $200 \mathrm{~g}$ each per week for a 7-week period in late winter and early spring suffered losses in body weight that averaged $5.8 \mathrm{~g}$ for those on normal corn and $65.5 \mathrm{~g}$ for those on high-lysine corn (Table 9). Both groups of hens suffered rather drastic losses in weight during the first week of the feeding trial. However, the hens fed normal corn essentially recovered their first-week loss in weight during the subsequent 6 weeks whereas those fed high-lysine corn continued to lose weight throughout the remainder of the feeding trial (Fig. 3).

Table 9.-Bady weight statistics far adult hen pheasants fed exclusive diets af $200 \mathrm{~g}$ of normal carn or af $200 \mathrm{~g}$ af high-lysine corn per hen per week for a 7-week periad, March 6-April 24, 1967.

Mean Body Weight $(\mathrm{g})$ or

Weight Change for

Specified Diet

\begin{tabular}{lccc}
\cline { 2 - 3 } & $\begin{array}{c}\text { Normal Corn } \\
\text { ( } \mathrm{n}=6 \text { Hens) }\end{array}$ & $\begin{array}{c}\text { High-Lysine Corn } \\
(\mathrm{n}=6 \text { Hens })\end{array}$ & F Values(de) \\
\hline Initial weight (March 6) & $907.3 \pm 40.6^{\circ}$ & $900.3 \pm 22.1$ & $0.02_{1,10}$ \\
Final weight (April 24) & $901.5 \pm 38.6$ & $834.8 \pm 26.3$ & $2.03_{1,10}$ \\
Weight change & $-5.8 \pm 25.9$ & $-65.5 \pm 26.4$ & $2.59_{1,10}$ \\
\hline
\end{tabular}

- Standard errors.

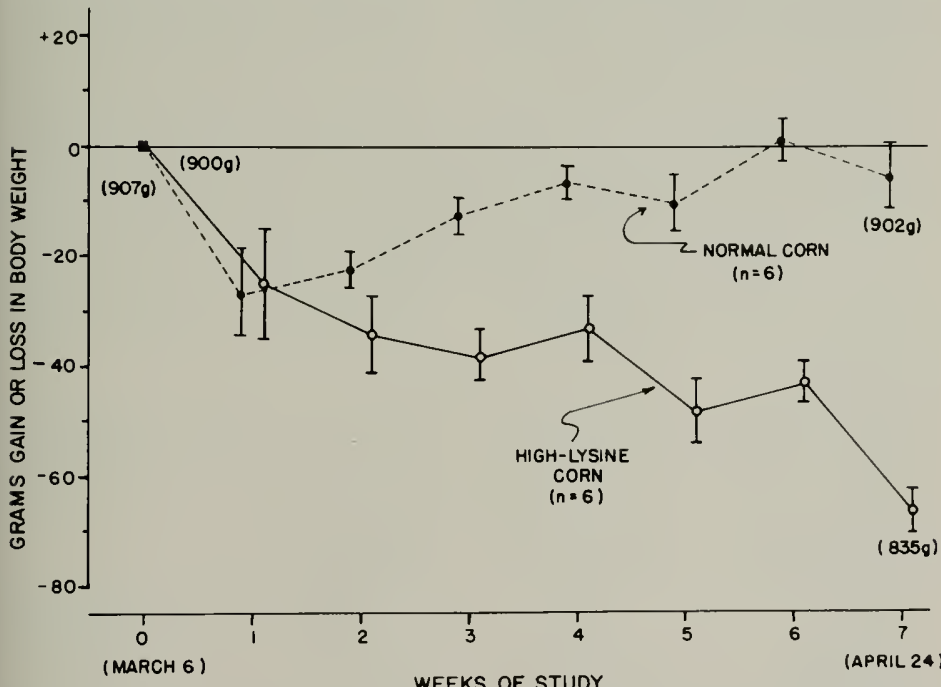

Fig. 3- Mean change in bady weight $(\mathrm{g})$ by weekly periads among adult hen pheasants fed exclusive diets af narmal carn ar af lysine corn; the vertical lines transecting the means are standard errars. The mean initial and final body weights far each graup are given at the left and right of the graph, respectively. Statistica.ly significant $(P<0.05,1$ and $10 \mathrm{df})$ weight changes accurred between diels far only ane af the seven successive weekly periods: 2 ta 3 ( $F=6.14)$. 
The changes in body weight recorded for the 7-week period for the six hens in each group were $+73,+40$, $+40,-54$, -60 , and $-68 \mathrm{~g}$ for normal corn, and $+16,-19,-39,-72,-126$, and $-153 \mathrm{~g}$ for high-lysine corn.

\section{Digestibility Coefficients}

With both corn diets restricted to 200 g per hen per week, each hen consumed the total offering, and hence an identical amount of corn. The digestion of the two corns by the adult hens, however, differed significantly, averaging 81.3 percent for normal corn and 76.9 percent for high-lysine corn (Table 10).

\section{Calorie Utilization}

The number of calories consumed by the adult hens was similar for the diets of normal corn and high-lysine corn (Table 11). Yet, both the proportionate and absolute utilization of calories differed significantly between the two groups of hens, being greater for those fed normal corn than for those fed high-lysine corn. The adult hens metabolized 3,921 ( 84.3 percent) and 3,617 (79.6 percent) kcal per $\mathrm{kg}$ of normal corn and high-lysine corn, respectively.

\section{Protein Utilization}

The intake of crude protein was similar for the adult hens on each of the two corns because the corns were fed at identical rates and had similar protein contents (Tables 1 and 10). However, both the proportionate and absolute utilization of crude protein by the adult hens differed significantly between the two diets, with the efficiency of protein utilization being greater for hens fed normal corn than for those fed high-lysine corn (Table 10).

\section{Lysine Utilization}

The intake of lysine by hens fed highlysine corn was about 42 percent greater

Table 10.-Comporative utilization of exclusive diets af narmal corn and of high-lysine corn, fed of a restricted rate of $200 \mathrm{~g}$ per hen per week, by adult hen pheasants for a 7 -week period, March 6-April 24, 1967. All values expressed as dry weight.

\begin{tabular}{|c|c|c|c|}
\hline & \multicolumn{2}{|c|}{$\begin{array}{l}\text { Mean Value per Hen per Week } \\
\text { for Specified Diet }\end{array}$} & \multirow[b]{2}{*}{$F$ Values(ar) } \\
\hline- & $\begin{array}{c}\text { Normal Corn } \\
(n=6 \text { Hens })\end{array}$ & $\begin{array}{l}\text { High-Lysine Corn } \\
\text { ( } \mathrm{n}=6 \text { Hens })\end{array}$ & \\
\hline Food consumed $(\mathrm{g})^{a}$ & 200 & 200 & \\
\hline $\begin{array}{l}\text { Crude protein } \\
\text { consumed }(\mathrm{g})\end{array}$ & 24.0 & 23.4 & \\
\hline Lysine consumed $(\mathrm{g})^{\circ}$ & 0.8 & 1.1 & \\
\hline Excreta $(\mathrm{g})^{d}$ & $37.1 \pm 0.6^{e}$ & $45.0 \pm 1.6$ & $18.85_{1,10} *$ \\
\hline $\begin{array}{l}\text { Digestibility } \\
\quad \text { coefficient (percent) }\end{array}$ & $81.3 \pm 0.2$ & $76.9 \pm 0.5$ & $54.07_{1,10} *$ \\
\hline $\begin{array}{l}\text { Crude protein in } \\
\text { excreta (percent) }\end{array}$ & $47.3 \pm 2.1$ & $44.0 \pm 2.7$ & $4.24_{1,10} *$ \\
\hline $\begin{array}{l}\text { Crude protein } \\
\text { utilized }(\mathrm{g})^{d} \\
\text { (percent) }\end{array}$ & $\begin{aligned} 6.3 & \pm 0.7 \\
26.3 & \pm 2.8\end{aligned}$ & $\begin{array}{r}3.6 \pm 0.7 \\
15.4 \pm 2.9\end{array}$ & $\begin{array}{l}8.64_{1,10} * \\
6.23_{1,10} *\end{array}$ \\
\hline $\begin{array}{l}\text { Change in body } \\
\text { weight }(\mathrm{g})\end{array}$ & -0.8 & -9.4 & \\
\hline
\end{tabular}

* Denotes statistical significance, $\mathbf{P}<0.05$. Interactions between weeks yielded no significant $\mathbf{F}$ values in any category.

a Each hen consumed the $200 \mathrm{~g}$ of food presented to it each week.

See Table 1 for protein content of food.

c Product of crude protein consumed and amount of lysine in protein.

¿ Based on data from Weeks 5 and 7 only.

- Standard errors. 
Table 11.-Comparative utilization of calories by adult hen pheasants fed a restricted diet of 200 $\mathrm{g}$ of normal corn ar $200 \mathrm{~g}$ af high-lysine corn per hen per week far a 7 -week periad, March 6April 24, 1967.

\begin{tabular}{|c|c|c|c|}
\hline & \multicolumn{2}{|c|}{$\begin{array}{l}\text { Mean Value per Hen per 7-Week Period } \\
\text { for Specified Diet }\end{array}$} & \multirow[b]{2}{*}{$F$ Values(dt) } \\
\hline & $\begin{array}{c}\text { Normal Corn } \\
(\mathrm{n}=6 \text { Hens })\end{array}$ & $\begin{array}{l}\text { High-Lysine Corn } \\
\quad(n=6 \text { Hens })\end{array}$ & \\
\hline Calories consumed (kcal) & $6,512^{a}$ & $6,362^{a}$ & \\
\hline Calories per $\mathrm{g}$ excreta ${ }^{b}$ & $3,925 \pm 26^{\circ}$ & $4,121 \pm 28$ & $3,897.40_{\mathrm{r}, \mathrm{zo}} *$ \\
\hline $\begin{array}{l}\text { Calories utilized } \\
{\text { (kcal })^{d}}^{(\text {percent })^{b}}\end{array}$ & $\begin{aligned} 5,492 & \pm 16 \\
84.3 & \pm 0.2\end{aligned}$ & $\begin{aligned} 5,066 & \pm 55 \\
79.6 & \pm 0.9\end{aligned}$ & $\begin{array}{r}17,095.46_{1,10} * \\
27.48_{1,10} *\end{array}$ \\
\hline
\end{tabular}

* Denotes statistical significance, $\mathbf{P}<0.05$.

a Each hen consumed the $200 \mathrm{~g}$ of fcod presented to it each week; hence, all hens on ecah of the two diets consumed the same number of kcal. See Table 1 for caloric content of corns.

Caloric values for Weeks 5 and 7 .

c Standard errors.

d Product of the 7-week consumption of calories and the 2-week (Weeks 5 and 7) percentage utilization of calories for each hen.

than among those hens fed normal corn (Table 12), the difference being attributable to the different proportions of lysine contained in the two corns (Table 1). The difference in proportionate utilization of the lysine between the two corns, although not statistically significant, was slightly greater among hens fed the highlysine corn. In the final analysis, the adult hens fed high-Jysine corn utilized about 33 percent more lysine during the feeding trial than did those hens fed an equivalent amount of normal corn. The response in body weight of the adult hens was not related to the amount of Jysine utilized during the 7-week trial ( $r=0.56$, $10 \mathrm{df} ; P>0.05)$.

\section{Glands and Organs}

Although the adult hens fed normal com and those fed high-lysine corn exhibited striking differences in the sizes of their organs, glands, and tissue masses (Table 13), none of the differences were statistically significant; there was, however, a pronounced pattern in the differences. Either the mean weight or the percentage of body weight (or both) of sternal muscles, fat strip, visceral fat, liver, ovary (and ovum), oviduct, and thyroids was larger for hens fed normal corn than for those fed high-lysine corn. The parathyroids and adrenals, however, were larger among hens on the high-ly-

Table 12.-Comparative utilization of lysine by odult hen pheosants fed a restricted diet of 200 9 af narmal carn or $200 \mathrm{~g}$ of high-lysine carn per hen per week for a 7 -week period, March 6April 24, 1967.

\begin{tabular}{|c|c|c|c|}
\hline & \multicolumn{2}{|c|}{$\begin{array}{l}\text { Mean Value per Hen per 7-Week Period } \\
\text { for Specified Diet }\end{array}$} & \multirow[b]{2}{*}{$F$ Values $(d t)$} \\
\hline & $\begin{array}{l}\text { Normal Corn } \\
(\mathrm{n}=6 \text { Hens })\end{array}$ & $\begin{array}{l}\text { High-Lysine Corn } \\
(\mathrm{n}=6 \text { Hens })\end{array}$ & \\
\hline Lysine consumed (g) & $5.4^{\mathrm{a}}$ & $7.7^{\circ}$ & \\
\hline $\begin{array}{l}\text { Lysine utilized } \\
(\mathrm{g})^{\circ} \\
(\text { percent })^{\circ}\end{array}$ & $\begin{aligned} 4.6 & \pm 0.1 \\
85.4 & \pm 0.9^{d}\end{aligned}$ & $\begin{array}{r}6.9 \pm 0.2 \\
89.0 \pm 2.0\end{array}$ & $\begin{array}{r}192.88_{1,10} * \\
2.76_{1,10}^{*}\end{array}$ \\
\hline
\end{tabular}

* Denotes statistical significance, $\mathrm{P}<0.05$.

a All hens consumed the $200 \mathrm{~g}$ of food presented to them each week; hence, each hen within each dietary group consumed the same amount of lysine.

broduct of the 7-week consumption of lysine and the 2-week (Weeks 5 and 7) percentage utilization of lysine for each hen.

i Utilization values for Weeks 5 and 7 .

d Standard errors. 
Toble 13.- Meon weights of selected tissues, organs, and glands from two groups of odult hen pheosonts thot were fed, respectively, normal carn or high-lysine corn for o 7-week period, Morch 6April 24, 1967. There were no significant differences between paired means $(P>0.05 ; 1$ and $10 \mathrm{df})$,

\begin{tabular}{|c|c|c|c|c|c|}
\hline \multirow[t]{2}{*}{$\begin{array}{c}\text { Tissue } \\
\text { Organ, } \\
\text { or Gland } \\
\end{array}$} & \multicolumn{2}{|l|}{$\begin{array}{c}\text { Normal } \\
\text { Corn } \\
(\mathrm{n}=6)\end{array}$} & $\begin{array}{c}\text { High-Lysine } \\
\text { Corn } \\
(n=6)\end{array}$ & $\begin{array}{c}\text { Normal } \\
\text { Corn }\end{array}$ & $\begin{array}{c}\text { High-Lysine } \\
\text { Corn }\end{array}$ \\
\hline & \multicolumn{3}{|c|}{ Grams } & \multicolumn{2}{|c|}{ Percent of Final Body Weight } \\
\hline Sternal muscies & 212.5 & 11.8 & $205.2 \pm 4.7$ & $23.5 \pm 0.6$ & $24.7 \pm 1.0$ \\
\hline Fat strip & $2.92 \pm$ & 0.57 & $1.46 \pm 0.45$ & $0.32 \pm 0.06$ & $0.17 \pm 0.05$ \\
\hline Visceral fat & $25.3 \pm$ & 5.9 & $13.4 \pm 4.6$ & $2.79 \pm 0.63$ & $1.53 \pm 0.51$ \\
\hline Liver & 15.0 & 1.2 & \pm 0.6 & $1.65 \pm 0.07$ & $1.60 \pm 0.08$ \\
\hline Ovary & $7.6 \pm$ & 2.8 & $3.1 \pm 0.3$ & $0.83 \pm 0.30$ & $0.37 \pm 0.03$ \\
\hline Largest ovum & $2.65 \pm$ & 1.13 & $0.70 \pm 0.21$ & $0.29 \pm 0.12$ & $0.08 \pm 0.03$ \\
\hline \multirow[t]{2}{*}{ Oviduct } & $11.6 \pm$ & 1.4 & $7.7 \pm 1.3$ & $1.27 \pm 0.13$ & $0.93 \pm 0.16$ \\
\hline & \multicolumn{3}{|c|}{ Milligrams } & \multicolumn{2}{|c|}{ Percent $\left(\mathrm{X} \mathrm{10^{s }}\right)$} \\
\hline Thyroids & 64.9 & 11.9 & \pm 7.3 & $71.5 \pm 12.3$ & \pm 7.9 \\
\hline Parathyroids & 9.9 & 0.8 & \pm 2.3 & \pm 1.2 & \pm 2.3 \\
\hline Adrenals & 93.0 & 4.5 & \pm 9.1 & \pm 5.6 & \pm 9.4 \\
\hline
\end{tabular}

sine diet than among those on the normal corn diet. This pattern of difference in weights of tissues, organs, and glands between the normal corn diet and the highlysine corn diet for adult hens was nearly the exact opposite of that observed among the juvenile hen pheasants.

\section{Fat and Fatty Acids}

The visceral fat from adult hens fed normal corn showed slightly greater amounts of saturated fatty acids and correspondingly lesser amounts of unsaturated fatty acids than did that from hens fed high-lysine corn (Table 8). The ratios of saturated to unsaturated fatty acids in the visceral fat were about 28:72 for the adult hens fed normal corn and 23:77 for those fed high-lysine corn.

\section{DISCUSSION}

The 8-week feeding trial with juvenile hen pheasants, which was conducted between mid-October and mid-December, coincided with that period of the year during which wild hen pheasants of comparable ages are gaining in body weight. To illustrate, the body weights of wild juvenile hens captured by nightlighting in east-central Illinois during the 6 years $1956-1961$ averaged $833 \mathrm{~g}(n=447)$ in
October and $943 \mathrm{~g}(\mathrm{n}=92)$ in December (R. F. Labisky, unpublished data), which represented gains of $110 \mathrm{~g}$, or 13.2 percent per hen during the 2 months.

The juvenile hens in the present study posted 2-month changes in mean body weight of $+13.8,+3.1$, and -1.2 percent on exclusive, ad libitum diets of FMC, high-lysine corn, and normal corn, respectively (Table 2). Wild juvenile hens must supplement their corn-dominated autumn diets with food items more nutritious than corn to post the weight gains that they normally exhibit in autumn. However, as a staple food, highlysine corn appears to be more favorable than normal corn in supplying the demands for growth by young pheasants, at least when both corns are available in an unrestricted supply.

If not restricted in their food intake, yearling and adult hens usually gain weight throughout late winter and early spring, reaching their maximum weight in April just prior to the onset of egglaying (Kirkpatrick 1944:178; Breitenbach et al. 1963:25-26; Gates \& Woehler 1968:235-238; Anderson 1972:467). The hens in this study, when fed restricted diets of corn during a 7-week span in March and April, averaged weight losses of 0.6 and 7.3 percent on diets of normal 
corn and high-lysine corn, respectively; their final body weights averaged 200$300 \mathrm{~g}$ below normal weights reported for adult hens at the initiation of egg-laying by Breitenbach (1963:26), Labisky \& Jackson (1969:720), and Anderson (1972: 459).

Any meaningful discussion of the physiological responses of pheasants to diets of normal corn and high-lysine corn must be prefaced by some knowledge of the nutritional requirements of the species. Unfortunately, data regarding nutritional requirements of pheasants are scarce, particularly for subadult birds, and must be extrapolated from information available for poultry. The National Research Council (1971:15-16) lists the minimum metabolizable energy (ME) requirements for domestic chickens ( $\mathrm{Gal}$ lus gallus) and turkeys (Meleagris gallopavo) as 2,900-3,095 kcal per $\mathrm{kg}$ of food for 14- to 20-week-old birds, and as 2,850 kcal for mature breeders. Thus, the ME obtained by pheasants, both juveniles and adults, from the normal corn and high-lysine corn fed in this study well exceeded the energy levels required by poultry (Table 14). The FMC, however, only provided growing pheasants 2,837 $\mathrm{kcal}$ of ME per $\mathrm{kg}$ of ration, slightly less than the minimum ME required by growing poultry. However, Barrett \& Bailey $(1972: 14,16-17)$ recently reported that breeding pheasants can perform satisfactorily on diets containing about 2,500 $\mathrm{kcal}$ of ME per $\mathrm{kg}$ of ration if the protein level is above 13 percent.

The rates of metabolizability of both normal corn and high-lysine corn by juvenile and adult hen pheasants in this study paralleled closely the general 80 percent metabolizability rate of normal corn by chickens (Ewing 1963:83). However, among pheasants, the metabolizability of normal corn was slightly greater than for the high-lysine corn regardless of whether the corns were fed ad libitum to jureniles or in restricted quantities to adults (Tables 3 and 10). Also, juveniles metabolized proportionately more of each of the two corns than did adults, a difference that may have reflected the relative demands of growth.

Our study showed that although the juvenile hen pheasants utilized a similar

Toble 14.- - Levels of protein, metabolizoble energy, ond selected omino acids recommended for poultry feeds in relation to quontities supplied in diets fed to pheasonts during this sludy. All levels. except those for metobolizable energy, ore expressed as percentoges of totol diet.

\begin{tabular}{|c|c|c|c|c|c|c|}
\hline & \multicolumn{3}{|c|}{ Dietary Requirements" } & \multicolumn{3}{|c|}{$\begin{array}{c}\text { Foods Supplied 14- to 22-Week-OId } \\
\text { Pheasants in This Study }\end{array}$} \\
\hline & $\begin{array}{l}\text { Chickens: } \\
\text { 14-20 Weeks }\end{array}$ & $\begin{array}{c}\text { Turkeys: } \\
\text { 14-20 Weeks }\end{array}$ & $\begin{array}{l}\text { Chickens: } \\
\text { Breeders }\end{array}$ & FMIC & $\begin{array}{l}\text { Normal } \\
\text { Corn }\end{array}$ & $\begin{array}{c}\text { High-Lysine } \\
\text { Corn } \\
\end{array}$ \\
\hline Crude protein & 12.0 & 16.5 & 15.0 & 22.8 & 12.0 & 11.7 \\
\hline $\begin{array}{l}\text { Metabolizable energ } \\
\quad(\mathrm{kcal} / \mathrm{kg})\end{array}$ & rgy 2,900 & 3,095 & 2,850 & \multicolumn{3}{|c|}{$2,837^{b} 3,945^{b}(3,921)^{c} 3,808^{\circ}(3,617)^{\circ}$} \\
\hline $\begin{array}{l}\text { Selected amino acid } \\
\text { Arginine }\end{array}$ & 0.72 & 1.0 & 0.8 & 1.42 & $0.46,0.45^{d}$ & $0.79^{\circ}$ \\
\hline Lysine & 0.66 & 0.9 & 0.5 & 1.12 & $0.38,0.18^{d}$ & 0.55 \\
\hline Methionine & 0.24 & 0.31 & 0.28 & 0.32 & $0.14,0.09^{d}$ & $0.16^{\circ}$ \\
\hline Cystine & 0.21 & 0.21 & 0.25 & 0.23 & $0.14,0.09^{d}$ & $0.20^{\circ}$ \\
\hline Tryptophan & 0.12 & 0.15 & 0.11 & ' & $0.09,0.09^{d}$ & $0.15^{\circ}$ \\
\hline
\end{tabular}

a From National Research Council (1971:15-16); these levels are recommended for achieving satisfactory dietary responses by poultry.

i ME for juvenile hen pheasants.

diE for adult hen pheasants. from Cromwell et al. (1907:106) for normat corn containing 9.10 percent protein, and second value from National Kesearch Council (1971:28, 40) Jor normal corn (No. 2 yellow dent) containing 8.90 percent protein; values are probably conservative as regards Pioneer 3306.

Amino acids not measured in high-lysine corn. Value from Cromwell (1967:706) for opaque-2 corn containing 11.60 percent protein. $t$ Data not available.
Date 
number of calories on all three dietsFMC, normal corn, and high-lysine corn -the proportionate utilization of calories was inversely associated with caloric consumption (Tables 4 and 11). Barrett \& Bailey (1972:20), however, reported that breeder pheasants compensated for foods with low ME levels by increasing food consumption, and consequently maintained reasonably similar levels of caloric intake on diets containing from 2,100 to $3,400 \mathrm{kcal}$ of ME per $\mathrm{kg}$. This type of compensatory action did not occur among juvenile hen pheasants fed different diets in our study. The diets of these birds, however, were more variable in $\mathrm{ME}$, protein content, and amino acid patterns than the rations fed by Barrett and Bailey, and hence are not totally comparable.

In our study, the similarity in caloric utilization by juvenile pheasants among the diets characterized by different levels of ME was achieved not by compensatory caloric intake but by compensatory metabolizability. Furthermore, adult hens did not show a greater proportionate utilization of calories from the corn than did juveniles, even though they were fed a restricted ration and consumed fewer calories than they would have consumed on an ad libitum diet of corn.

The National Research Council (1971: 19) listed the dietary protein requirements for starting and growing pheasants at 30 percent. Dale \& DeWitt (1958: 292) reported that the growth rates of young pheasants, to 10 weeks of age, were less on diets containing 15, 18, and 22 percent protein than on diets containing 28 percent protein. The Council (1971:15-16) also listed the protein requirements of the chicken as 20-23 percent for chicks, 12-16 percent for growing chickens, and 15 percent for laying (breeding) chickens; comparable levels for domestic turkeys were 28, 14-20, and 14 percent, respectively. The reported protein content in the diets of wild hen pheasants in the Midwest ranged seasonally from a minimum of about 12 percent to a maximum of about 19 percent (Korschgen 1964:169, 174). Collectively, these findings suggest that the protein needs of pheasants are probably satisfactorily met at levels of $16-20$ percent for juveniles older than 14 weeks and 15 percent for adult breeders. Therefore, in this study, the dietary protein levels for pheasants were sufficient in the FMC (22.9 percent), but insufficient in both normal corn (12.0 percent) and highlysine corn (11.7 percent).

Whereas consumption of crude protein by the juvenile hen pheasants differed among birds fed FMC, normal corn, and high-lysine corn (Table 3), the proportionate utilization of the protein consumed, irrespective of amount, was similar on all diets. Thus, among juvenile pheasants the total amount of protein utilized was related directly to the amount consumed-a situation opposite that for caloric utilization.

Although adult hens consumed similar amounts of protein from the two corns, which were fed at a restricted rate, they utilized 41 percent less of the protein from high-lysine corn than from normal corn (Table 10). Thus, although both corns yielded dietary protein levels that were unsatisfactory to juveniles and adults, the pheasants still failed to utilize about three-fourths of all the protein they consumed in corn.

Eleven of the 23 verified amino acids in proteins are essential to birds; that is, they cannot be sufficiently synthesized by the bird and must be taken in via the diet. Ewing (1963:201, 203) points out that arginine, lysine, methionine, cystine, and tryptophan are particularly important to birds because they are essential amino acids that are in critical demand during avian growth and development; the other amino acids are either synthesized by the bird or are present in ample quantities in most foods.

Important to the understanding of the amino acid complex is the fact that a deficiency of any essential amino acid will not only reduce the utilization of other 
amino acids, but will also reduce the utilization of the entire diet. Thus, although this paper is concerned principally with the growth-associated amino acid, lysine, other amino acids that are potentially important to pheasants cannot be ignored. The FMC ration provided to pheasants in this study offered adequate quantities of protein and the essential amino acids for both subadult and adult birds (Table 14). The normal corn and high-lysine corn diets, while providing minimal amounts of protein, did not supply adequate quantities of amino acids. The amino acids most lacking in the corns were lysine and methionine. High-lysine corn, however, offered an amino acid profile superior to that of normal corn, and the profiles of both corns were more aligned with the requirements of adult birds than of growing pheasants.

The importance of lysine to growth was well illustrated in a study by Baldini et al. (1953:946-948). They demonstrated that young bobwhites (Colinus virginianus), which reportedly required diets with 28 percent protein, could surrive and grow well on diets containing as little as 20 percent protein as long as the diets contained adequate amounts of lysine. In their experiments, the addi: tion of 0.3 percent lysine to a base diet of 20 percent protein and 1.0 percent lysine produced a ration with growth and survival qualities for bobwhites that were equal to those provided by a diet containing 28 percent protein and 1.0 percent lysine; thus, 0.3 percent lysine essentially replaced 8.0 percent crude protein. Such findings offer support for our conclusion that the amount of lysine utilized by juvenile pheasants contributed more significantly to their growth than did the amount of crude protein utilized (Table 6).

As with crude protein, pheasants exhibited no compensatory utilization of lysine; the utilization of lysine was related directly to its intake for both juvenile and adult birds (Tables 5 and 12). Perhaps the most interesting observation was the extremely high utilization (99.2 percent) of lysine from high-lysine corn by juvenile pheasants. This rate of utilization was not maintained by adult hens.

The role of inadequate nutritionquantitative or qualitative-as regards the physiology of stress in vertebrates is poorly understood. Among mammals, the term "stress" has become almost synonymous with increased adrenocortical activity (see review by Christian 1963). Presumably, some adverse stimulus triggers, via the hypothalamus, an increased release of adrenocorticotropic hormone (ACTH), which in turn results in the increased production and secretion of corticosteroids from the adrenal cortex that are necessary for maintaining physiological homeostasis under the given stress. (Prolonged exposure by the animal to an adverse stimulus may result in exhaustion of the adrenal cortex, the subsequent failure of corticosteriod production, and finally death.) To produce the additional corticosteriods, the adrenal cortex undergoes hyperplasia and hypertrophy-hence, enlargement of the gland. Thus, enlarged adrenals have become generally recognized as clinical evidence of acute or chronic distress in mammals.

Whether enlarged adrenals are a measure of stress in birds is not clear. Like Christian \& Davis (1966:11-13), who found a direct relationship between adrenal size (of mature females) and population density for vole (Microtus pennsylvanicus) (Neave \& Wright 1968: $634)$ reported a positive correlution between adrenal-weight indices and population density for ruffed grouse (Bonasa umbellus). Breitenbach et al. (1963:34) reported that the adrenals of adult hen pheasants that were restricted in their food intake ( $45 \mathrm{~g}$ per day) did not hypertrophy; however, the adrenals of individual hens, in noticeably poor condition, exhibited a marked increase in size. Also, Newlon et al. (1964:538-539) observed that the adrenal weights of bobwhites were greatest for birds fed those foods which yielded the poorest perform- 
ance in maintaining body weight. These observations, coupled with our findings that the adrenal weights of hen pheasants were inversely related to changes in body weight (Table 7 and 13; Fig. 1-3), suggest to us that enlarged adrenals offer diagnostic symptoms of the stresses of inadequate nutrition in pheasants, and possibly other birds.

The deposition and inobilization of depot fats are dynamic processes-even in an animal in reasonably stable energy balance (White et al. 1968:500). We found that depot fat, both strip and visceral, was greatest for juvenile hen pheasants fed high-lysine corn, intermediate for those fed FMC, and least for those fed normal corn (Table 7). In contrast, adult hens, fed restricted but equal amounts of the two corns, accumulated greater fat deposits on a diet of normal corn than on a diet of high-lysine corn (Table 13). The fat deposits from these adult hens, irrespective of the type of corn diet, were many times smaller than those reported in spring for confined hens fed a high-protein ration ad libitum (Breitenbach 1963:32) or for wild hens (Anderson 1972:461). Breitenbach et al. (1963:34) presented evidence that the storage of fat may be stimulated by increased amounts of adrenocorticosteroids. Hence, if the production of corticosteroids paralleled increased adrenal size, as would be expected, fat deposits should have been related directly to adrenal size. We did not observe this relationship among the hens in this study. The birds' depot fats, which represent their largest reservoir of energy, were related to body weight, and therefore inversely reflected the hens' day-to-day energy demands.

Depot fat consists chiefly of triglycerides; fatty acids, both saturated and unsaturated, are hydrolized from triglycerides via the action of the lipases. We found that the ratios of saturated to unsaturated fatty acids in the visceral fat from juvenile and adult hen pheasants fed normal corn and from juvenile hens fed high-lysine corn were about 27:73 (Table 8). Correspondingly, normal corn and high-lysine corn contained saturated to unsaturated fatty acid ratios of $14: 86$ and 19:81, respectively (Table 1). Hence, there was some disparity in the distribution of saturated and unsaturated fatty acids between the depot fat of pheasants and their corn diets. Although the distribution of fatty acids in the depot fat of herbivorous galliform birds generally reflects the composition of the diet (Moss \& Lough 1968:559; West \& Meng $1968 b: 438)$, West \& Meng (1968a:539) have also provided evidence that, at least for the redpoll (Acanthis flammea), environmental conditions and the physiological state of the bird also influence the fatty acid composition of the visceral fat.

Interestingly, the ratio of saturated to unsaturated fatty acids in the visceral fat of the adult hens fed the restricted intake of high-lysine corn was 23:77, which represented an increase in unsaturated fatty acids over the $27: 73$ ratio recorded for juvenile hens fed either high-lysine corn or normal corn ad libitum and for adult hens fed the restricted diet of normal corn. The shift by adult hens fed high-lysine corn to a fatty acid composition of depot fat that more closely reflected that of their high-lysine corn diet is not surprising because White et al. (1968:499) reported that fatty acid profiles of depot fat resemble the dietary profiles more closely when the depot fat is being depleted. The adult hens fed high-lysine corn at the restricted rate were decreasing in body weight, and therefore probably drawing on the stores of saturated fatty acids for reserve energy. Under these conditions the replacement fatty acids reflected the high proportion of unsaturates in the high-lysine corn diet.

Plant seeds abound in unsaturated fatty acids. The principal unsaturated fatty acids in the corns were oleic and linoleic. Correspondingly, the principal fatty acids in the visceral fat of pheasants were oleic and linoleic (Table 8); however, the samples of visceral fat contained pro- 
portionally more oleic acid and considerably less linoleic acid than either of the corns. Linoleic was the principal fatty acid in the depot fats of the heather-eating red grouse (Lagopus lagopus scoticus) (Moss \& Lough 1968:560-561) and of the willow-eating willow ptarmigan ( $\mathrm{La}$ gopus lagopus alascensis) (West \& Meng $1968 b: 438$ ). However, as we found for the pheasant, Walker (1964:63-64) reported the predominant fatty acid in the depot fat of the seed-eating bobolink (Dolichonyx oryzivorus) to be oleic acid. Oleic acid and linoleic acid seem to be the principal unsaturated fatty acids that characterize the depot fats of granivorous and herbivorous birds, respectively.

The parathyroid glands secrete a hormone that functions importantly as a regulator of calcium, and probably phosphorus, metabolism; high and low levels of circulating calcium act on the glands to inhibit or stimulate, respectively, secretion of the parathyroid hormone (Geschwind 1961:434-436). Hypertrophied parathyroid glands and reduced levels of blood calcium are characteristic responses of laying chickens to low-calcium diets (Bloom et al. 1960:207). In our study, we fed juvenile hen pheasants diets that ranged from about $14,000 \mathrm{ppm}$ calcium for FMC to about $40 \mathrm{ppm}$ calcium for the corns (Table 1); corns in general are notoriously low in calcium content. The parathyroids from these juvenile hens fed normal corn and highlysine corn weighed at least twice as much as the glands from those fed F.MC (Table 7), and nearly twice as much as the glands from their wild counterparts (Anderson 1972:485). Furthermore, the adult hens fed exclusive diets of the corns during late winter and early spring ( Table 13) had parathyroids substantially larger than those reported by Anderson (1972:485) for wild adult hens at a comparable time of the year. The hypertrophied parathyroid glands from hen pheasants fed exclusive diets of calciumdeficient corns constituted strong clinical evidence that the birds were suffering from a negative calcium balance.
The gonadal recrudescence among pheasants in spring is a response, mediated via the hypothalamo-hypophyseal axis, to increasing photoperiod (Bissonnette \& Csech 1936:106; Hiatt \& Fisher 1947:538, 543; Greeley \& Meyer 1953: 353-354). In Illinois, complete gametogenesis among hens, as evidenced by egglaying, is attained between late March and mid-April (Labisky \& Jackson 1966: 382; Labisky 1968:69; Labisky \& Jackson 1969:719). In our study, none of the adult hens fed corn diets restricted to an intake of $200 \mathrm{~g}$ per week had initiated egg-laying at the conclusion of the experiment on April 24. Furthermore, the reproductive tracts of these hens, when compared to hens on unrestricted diets or in the wild (Breitenbach et al. 1963:29; Anderson 1972:484) were severely underdeveloped physiologically for late April. The lag in ovarian and oviducal development was more pronounced for hens fed high-lysine corn than for those fed normal corn (Table 13).

The findings from this and previous investigations of confined pheasants (Gerstell 1942:68; Kozlik 1949:62; Breitenbach et al. 1963:27; Gates \& Woehler 1968:240) have demonstrated that delays in egg-laying are related to poor physical condition in spring; Edwards et al. (1964:278) hypothesized a similar situation for wild pheasants. Also, poor physical condition, usually the result of malnutrition, signifies reduced reserves of energy. Fisher $(1967: 121)$ cited evidence to show that domestic hens would cease egg production as soon as their protein reserves were exhausted after being placed on a protein- or amino acid-deficient diet. Corns do not abound in protein, and are deficient in one or more of the essential amino acids.

The inhibitory effects of inadequate nutrition on reproduction in galliform birds, however, seem to be mediated through the hypothalamo-hypophyseal axis and not directly by protein or amino acid imbalances. Mforris \& Nalbandov (1961:687) demonstrated that undernourished or starved domestic pul- 
lets failed to produce sufficient gonadotropins to promote functional ovarian and oviducal development. Gates \& Woehler (1968:243) sum it up aptly: "It would appear that restoration of body condition [in pheasants] . . . is a requisite for recrudescence, normal rates of egg laying being delayed until energy is available for reproduction and the secretory integrity of the pituitary is restored."

The nutritional responses of pheasants to normal corn and high-lysine corn are not consistent for birds of different ages. The weight gains and physiological parameters for juvenile hen pheasants fed high-lysine corn in autumn were distinctly more favorable than for those correspondingly fed normal corn. Yet adult hens fared far better on normal corn as an emergency food in late winter than they did on high-lysine corn. Thus, although potentially of benefit to growing pheasants, high-lysine corn may well be a detriment to mature pheasants. These conflicting results are at least partially explainable. The greater nutritional value to young pheasants of high-lysine corn, when contrasted with normal corn, undoubtedly lies in its higher content of the growth-oriented amino acid, lysine. Our findings indicated strongly that the weight gains of juvenile pheasants were dependent directly on the amount of lysine utilized. Evidence in support of these findings is provided by the research of Cromwell et al. (1967:711), wlio studied the nutritional responses of domestic chicks to the two corns: ". . . the beneficial effects of opaque-2 corn over normal corn appeared to be mediated solely through its higher lysine content." These workers, however, fed the corns as a part of nutritionally balanced basal diets, and not as exclusive food items. They also pointed out (p. 712) that the beneficial responses exhibited by young animals to opaque-2 corn would probably be much less for mature animals that have a lower protein requirement. Furthermore, the probability of selecting genetically for a pheasant that responds to higher than normal dietary levels of lysine by exhibiting an improved rate of growth seems remote, as Godfrey (1968: 1565) found that the heritability for lysine utilization among Japanese quail (Coturnix coturnix japonica) was very low. Thus opaque-2 corn apparently is not a panacea for assuring adequate nutrition in pheasants. Another modifiedprotein corn called floury-2, which contains higher concentrations of both lysine and methionine than those in most other corns (Nelson et al. 1965:1470; Cromwell et al. 1968:846), may offer nutritional benefits for birds that are potentially superior to those provided by either normal corn or opaque-2 corn.

Corn, an important food source to many species of wildlife, is a nutritive staple for pheasants. To illustrate, Newlon et al. (1964:536-537), in evaluating foods for sustaining bobwhites, reported that the mean survival duration for juvenile and adult birds fed an exclusive, ad libitum diet of normal corn in November was 22.6 days; no bobwhite survived the 38-day feeding trial. As observed in this study, however, exclusive ad libitum diets of normal corn sustained juvenile pheasants, with only minor weight losses, for 8 weeks in autumn without any mortality. Also, adult hens fed a restricted intake of normal corn (200 $g$ per week) in late winter and early spring maintained their body weights for a 7 -week feeding trial. If, however, pheasants are to parallel the annual cycle of body weights that normally characterize thriving populations in the wild they must supplement their corn-dominated diets with food items more nutritiously balanced than high-lysine or normal corn. A plausible hypothesis, therefore, is that the high rates of nonhunting mortality observed among wild juvenile pheasants in Illinois during autumn (R. F. Labisky, unpublished data) may be directly or indirectly related to nutritive imbalances resulting from the surging availability of waste corn in the birds' diet. 


\section{SUMMARY}

Corn is an important food for many wild animals and is especially prominent in the diet of wild pheasants in the United States. Yet despite its importance as a staple food of pheasants, knowledge of its nutritional value to the species is still quite limited. In 1963, scientists added another dimension to corn nutrition by discovering a modified-protein corn, opaque-2 corn (herein called high-lysine corn), which has substantially greater amounts of lysine in its endosperm than does normal corn. Lysine is one of the essential growth-promoting amino acids.

The objectives of this investigation were to ascertain the physiological responses of juvenile hen pheasants in autumn, and of adult hens in late winter and early spring to exclusive diets of normal corn and high-lysine corn. In the 8-week feeding trial for juveniles, October 20-December 15, 1966, 21 hens in three groups of 7 each were fed exclusive, ad libitum, diets of a balanced ration (FMC), normal corn, or highlysine corn. Analyses of the three foods yielded the following: FMC $-4.28 \mathrm{kcal}$ per $\mathrm{g}, 22.8$ percent protein, and 4.9 percent lysine in protein; normal corn-4.65 kcal per g, 12.0 percent protein, and 3.2 percent lysine in protein; and high-lysine corn-4.54 kcal per g, 11.7 percent protein, and 4.7 percent lysine in protein. The feeding trial for juveniles coincided with the season in which juvenile hens, in contrast to adult hens, suffer disproportionately high rates of nonhunting mortality in Illinois, and also simultaneously with the time that waste corn from the harvest suddenly becomes an abundant food source. Hence this phase of the study was designed partially to determine if juvenile mortality among wild pheasants was related to unbalanced nutrition. In the 7-week feeding trial for adult hens, March 6-April 24, 1967, 12 hens in two groups of 6 each were fed exclusive diets of normal corn or highlysine corn at the restricted rate of 200 g per bird per week. This restricted intake of food was intended to simulate the conditions that wild hens in the Midwest often confront in late winter and early spring.

The juvenile hen pheasants fed exclusive diets of FMC and high-lysine corn for the 8-week period in autumn posted gains in body weight that averaged $98.4 \mathrm{~g}$ (13.8 percent) and $23.4 \mathrm{~g}$ (3.1 percent), respectively; correspondingly those juvenile hens fed normal corn suffered average losses of $8.7 \mathrm{~g}$ ( 1.2 percent). Wild juvenile hens averaged gains of $110 \mathrm{~g}$ (13.2 percent) for the comparable autumn period.

Adult hens, each fed a restricted intake of $200 \mathrm{~g}$ of corn per week for the 7 -week period in late winter and early spring, averaged losses in body weight of $5.8 \mathrm{~g}$ (0.6 percent) for normal corn and $65.5 \mathrm{~g}$ (7.3 percent) for high-lysine corn. Whereas hen pheasants usually exhibit gains in body weight in late winter, reaching their maximum weight just prior to the onset of egg-laying (usually in April), the adult hens on the restricted intake of corn averaged $200-300 \mathrm{~g}$ below the normal body weights of wild hens in April.

The kcal of energy metabolized per $\mathrm{kg}$ of food consumed by juvenile hens was 2,837 (66.3 percent efficiency) for FMC, 3,945 (84.8 percent) for normal corn, and 3,808 (83.3 percent) for high-lysine corn; adult hens metabolized 3,921 kcal per $\mathrm{kg}$ (84.3 percent) of normal corn and $3,617 \mathrm{kcal}$ per $\mathrm{kg}$ (79.6 percent) of high-lysine corn. Juvenile hens, despite the differences in the yield of metabolizable energy among the foods, utilized the same number of calories on all three diets; the similarity in caloric utilization was achieved by compensatory metabolizability and not by compensatory caloric intake.

Unlike the situation for calories, hen pheasants exhibited no compensatory utilization of either crude protein or lysine. The total amounts of both protein and lysine utilized by hen plieasants 
were related directly to dietary intake. Even though the dietary protein levels of both corns were unsatisfactory, the birds utilized only about one-fourth of the protein they consumed. The proportionate utilization of lysine by either adult or juvenile hens exceeded 85 percent for all diets. Interestingly, juvenile hens utilized 99 percent of the lysine consumed from high-lysine corn-a rate not achieved by adult hens. Most important was the finding that the body weights of juvenile pheasants in autumn were more dependent on the amount of lysine utilized than on the amount of crude protein utilized.

The adrenal weights of hen pheasants were inversely related to changes in body weight, which in turn was a reflection of the consumption of diets of different nutritional offerings. These findings indicated that enlarged adrenal glands in pheasants, and possibly other avian species, may offer diagnostic evidence for detecting the physiological stresses of unbalanced or inadequate nutrition.

Depot fats of hen pheasants were directly related to changing body weight, a relationship that reflected changing demands for energy for growth or maintenance. The ratio of saturated: unsaturated fatty acids in the visceral fat of hens fed corn was about $1: 3$, which was greater than that found in the corns. Oleic and linoleic were the principal fatty acids in corn, and, correspondingly, the most prominent in the depot fats of pheasants.

Hypertrophied parathyroid glands from hen pheasants fed exclusive diets of calcium-deficient corns offered strong clinical evidence that wild hen pheasants on corn-dominated diets would suffer from a negative calcium balance.

The reproductive tracts of adult hen pheasants fed restricted diets of normal corn or high-lysine corn, unlike those of wild hens or hens fed unrestricted diets, were severely underdeveloped in late April. The lag in ovarian and oviducal development was substantially greater for hens fed high-lysine corn than for those hens fed normal corn. The effects of inadequate nutrition are apparently mediated through the hypothalamo-hypophyseal-gonadal axis.

The nutritional responses of young and adult hen pheasants to normal corn and high-lysine corn were not similar. The physiological profiles of juvenile hens fed high-lysine corn in autumn were distinctly more favorable than of those fed normal corn. The greater nutritional value to young pheasants of high-lysine corn, in contrast to normal corn, very likely is associated with its higher content of lysine, an essential growth-promoting amino acid. However, as an emergency food for adult hens in late winter or early spring, normal corn proved superior to high-lysine corn.

To attain the physiological plateaus that normally characterize self-maintaining populations in the wild, pheasants must supplement their corn-dominated diets with foods more nutritiously balanced than corn-high-lysine corn not excepted. Dietary imbalances, resulting from the surging availability of waste grain from the corn harvest, may be associated with the high rates of nonhunting mortality among juvenile hen pheasants in Illinois during autumn. 


\section{LITERATURE CITED}

Adams, R. L., and J. C. Rogler. 1970. A comparison of opaque-2 and normal corn in a finishing ration for turkeys. Poultry Science $49(4): 1114-1116$.

ANDERsoN, WilliaM L. 1972. Dynamics of condition parameters and organ measurements in pheasants. Illinois Natural History Survey Bulletin $31(8): 455-498$.

and Peggy L. Stewart. 1969. Relationships between inorganic ions and the distribution of pheasants in Illinois. Journal of Wildlife Management 33(2) :254-270.

Baldini, James T., Roy E. Roberts, and Charles M. Kirkpatrick. 1953. Low protein rations for the bobwhite quail. Poultry Science $32(6)$ : 945-949.

Barrett, Morley W., and Edward D. Bailey. 1972. Influence of metabolizable energy on condition and reproduction of pheasants. Journal of Wildlife Management 36(1): 12-23.

Bissonnette, Thomas Hume, and Albert G. Csech. 1936. Fertile eggs from pheasants in January by "night-lighting". Bird Banding $7(3): 108-111$.

Blooir, W., A. V. Nalbandov, and M. A. BLoox. 1960. Parathyroid enlargement in laying hens on a calcium-deficient diet. Clinical Orthopaedics 17:206-209.

Breitenbach, Robert P., and Roland $K$. MEYer. 1959. Effect of incubation and brooding on fat, visceral weights and body weight of the hen pheasant (Phasianus colchicus). Poultry Science 38(5):10141026.

- Clarence L. Nagra, and Roland K. MEYER. 1963. Effect of limited food intake on cyclic annual changes in ringnecked pheasant hens. Journal of Wildlife Management 27(1):24-36.

Christian, J. J. 1963. Endocrine adaptive mechanisms and the physiologic regulation of population growth, p. 189-353. In William V. Mayer and Richard G. Van Gelder (Editors), Physiological mammalogy, Volume 1. Academic Press, New York and London. 381 p.

Christian, John J., and David E. Davis. 1966. Adrenal glands in female voles ( $\mathrm{Mi}$ crotus pennsylvanicus) as related to reproduction and population size. Journal of Mammalogy $47(1): 1-18$.

Cromwell, G. L., J. C. Rogler, W. R. Featherston, and T. R. Cline. 1968. A comparison of the nutritive value of opaque-2, floury-2 and normal corn for the chick. Poultry Science $47(3): 840-847$.

1967. Nutritional value of opaque-2 corn for the chick. Poultry Science 46(3) : 705712.
Dale, Fred H., and James B. DeWitt. 1958. Calcium, phosphorus and protein levels as factors in the distribution of the pheasant. North American Wildlife Conference Transactions 23:291-294.

Edwards, William R., Peter J. Mikolaj, and EDWARD A. LeITE. 1964. Implications from winter-spring weights of pheasants. Journal of Wildlife Management 28(2): 270-279.

EWING, W. Ray. 1963. Poultry nutrition. Fifth edition (revised). The Ray Ewing Company, Pasadena, California. 1,475 p.

Fisher, HaNs. 1967. Nutritional aspects of protein reserves, p. 101-124. In Anthony A. Albanese (Editor), Newer methods of nutritional biochemistry with applications and interpretations, Volume 3. Academic Press, New York and London. 527 p.

Gates, John M., and Eugene E. Woehler. 1968. Winter weight loss related to subsequent weights and reproduction in penned pheasant hens. Journal of Wildlife Management $32(2): 234-247$.

Gerstell, Richard. 1942. The place of winter feeding in practical wildlife management. Pennsylvania Game Commission Research Bulletin 3. $121 \mathrm{p}$.

Geschwind, Irving J. 1961. Hormonal control of calcium, phosphorus, iodine, iron, sulfur, and magnesium metabolism, p. 387472. In C. L. Comar and Felix Bronner (Editors), Mineral metabolism, Volume 1, Part B. Academic Press, New York and London. P. 387-879.

Godfrey, Edward F. 1968. Ten generations of selection for lysine utilization in Japanese quail. Poultry Science $47(5)$ :15591566.

Greeley, Frederick, and Roland K. Meyer. 1953. Seasonal variation in testis-stimulating activity of male pheasant pituitary glands. Auk $70(3): 350-358$.

Harper, Alfred E. 1967. Effects of dietary protein content and amino acid pattern on food intake and preference, p. 399-410. In Handbook of physiology, Section 6 (Charles F. Code, Editor): Alimentary canal, Volume 1. Control of food and water intake. American Physiological Society, Washington, D.C. 459 p.

Hiatt, Robert W., and Harvey I. Fisher. 1947. The reproductive cycle of ring-necked pheasants in Montana. Auk 64(4):528548.

Hudson, George E., and Patricia J. Lanzillottr. 1964. Muscles of the pectoral limb in galliform birds. American Midland Naturalist $71(1): 1-113$. 
Jensen, A. H., D. E. Becker, and B. G. Harmon. 1967. Opaque-2 corn, milo and wheat in diets for finishing swine. Journal of Animal Science 26(6):1473 (Abstract).

Kirkpatrick, C. M. 1944. Body weights and organ measurements in relation to age and season in ring-necked pheasants. Anatomical Record 89(2): 175-194.

Korschaen, Leroy J. 1964. Foods and nutrition of Missouri and midwestern pheasants. North American Wildlife and Natural Resources Conference Transactions 29:159180.

Kozlik, Frank M. 1949. Pheasant-quail management research: pheasant section. Wisconsin Wildlife Research 8(1):51-64.

Labisky, Ronald F. 1968. Ecology of pheasant populations in Illinois. Ph.D. Thesis. University of Wisconsin, Madison. $511 \mathrm{p}$. -, and Gary L. Jackson. 1966. Characteristics of egg-laying and eggs of yearling pheasants. Wilson Bulletin 78(4):379-399. - and 1969 . Production and weights of eggs laid by yearling, 2-, and 3year-old pheasants. Journal of Wildlife Management 33(3):718-721.

Mertz, Enwin T. 1966. Growth of rats on opaque-2 maize, p. 12-18. In Edwin $\mathrm{T}$. Mertz and Oliver E. Nelson (Editors), Proceedings of the high lysine corn conference. Corn Industries Research Foundation, Corn Refiners Association, Inc., Washington, D.C. 186 p.

- LynN S. Bates, and Oliver E. Nelson. 1964. Mutant gene that changes protein composition and increases lysine content of maize endosperm. Science 145 (3629) : 279-280.

- , Olivia A. Vernon, Lynn S. Bates, and Oliver E. Nelson. 1965. Growth of rats fed on opaque-2 maize. Science 148 (3678) : 1741-1742.

Morris, T. R., and A. V. Nalbandov. 1961. The induction of ovulation in starving pullets using mammalian and avian gonadotropins. Endocrinology 68(4):687-697.

Moss, R., and A. K. Lougr. 1968. Fatty acid composition of depot fats in some game birds (Tetraonidae). Comparative Biochemistry and Physiology 25(2):559-562.

National Research Council. 1971. Nutrient requirements of domestic animals.
Number 1, Nutrient requirements of poultry. Sixth edition (revised). National Academy of Sciences, Washington, D.C. $54 \mathrm{p}$.

Neave, David J., and Bruce S. Wright. 1968. Ruffed grouse adrenal weights related to population density. Journal of Wildlife Management 32(3):633-635.

Nelson, Oliver E., Edwin T. Mertz, and Lynn S. BAtes. 1965. Second mutant gene affecting the amino acid pattern of maize endosperm proteins. Science 150(3702): 1469-1470.

Newlon, Charles F., Thomas S. Baskett, Robert P. Breitenbach, and Jack A. STANFORD. 1964. Sustaining values of emergency foods for bobwhites. Journal of Wildlife Management 28(3):532-542.

Pickett, Richard A. 1966. Opaque-2 corn in swine nutrition, p. 19-22. In Edwin T. Mertz and Oliver E. Nelson (Editors), Proceedings of the high lysine corn conference. Corn Industries Research Foundation, Corn Refiners Association, Inc., Washington, D.C. 186 p.

Rogler, John C. 1966. A comparison of opaque-2 and normal corn for the chick, p. 23-25. In Edwin T. Mertz and Oliver E. Nelson (Editors), Proceedings of the high lysine corn conference. Corn Industries Research Foundation, Corn Refiners Association, Inc., Washington, D.C. 186 p.

Walker, Alma Toers. 1964. Major fatty acids in migratory bird fat. Physiological Zoology 37(1):57-64.

West, George C., and Martha S. Meng. $1968 a$. The effect of diet and captivity on the fatty acid composition of redpoll (Acanthis flammea) depot fats. Comparative Biochemistry and Physiology 25(2):535540.

- , and - 1968 b. Seasonal changes in body weight and fat and the relation of fatty acid composition to diet in the willow ptarmigan. Wilson Bulletin $80(4): 426^{-}$ 441.

White, ABraham, Philip Handler, and Emil L. Sмiтh. 1968. Principles of biochemistry. Fourth edition. The Blakiston Division, McGraw-Hill Book Company, Inc., New York. 1187 p. 


\section{INDEX}

A

Acanthis flammea (see redpoll)

Adrenal glands

as indicator of stress, 103, 108

mean weights of, 95,100

weight correlated with body weight, 94 , 96

Adrenocortical activity, 103

Adrenocorticosteroids, 104

Adrenocorticotropic hormone (ACTH), 103

Amino acids

analyzer, 90

requirements for, 101

essential to birds, 102

Arachidonic acid, 96

Arginine, 101, 102

Atomic absorption spectrophotometry, 90

B

Bobolink, 105

Bobwhite, 103, 106

Body weight

changes in, 90-91, 97, 107

correlated with adrenal weight, 94,96

correlated with lysine utilization, 93-94

correlated with protein utilization, 93,94

of wild pheasants, 100

procedures for recording, 89

Bonasa umbellus (see ruffed grouse)

C

Calcium, 89, 90, 105, 108

Calories

consumption of, $93,98,99$

determination of, 90

in experimental diets, 89,107

utilization of, 92, 93, 98, 99

Care and housing of pheasants, 88

Chicken, 87, 101, 102,105, 106

Colinus zirginianus (see bobwhite)

Colorimetr: 90

Coracobrachialis, 89

\section{Corn}

as food for wild animals, 87,107

chemical composition of, 89, 101

metabolizable energy (ME) of, 101

Pioneer 3306, 88, 89

Corticosteroids, 103, 104

Coturnix coturnix japonica (see Japanese quail)

Cystine, 101, 102

\section{D}

\section{Diets}

chemical composition of, 89,101

Digestibility coefficients

defined. 91

for experimental diets, 91-92, 98

Dissecting procedures, 89

Dolichon yx oryzivorus (see bobolink)
E

Egg-Jaying

timing of, 105

Excreta

mean weights of, 92,98

procedures for collecting, 89

\section{$\mathrm{F}$}

Fat deposits

deposition and mobilization, 104

mean weights of, 95, 100

Fat strip (see fat deposits)

Fatty acids

in experimental diets, 89

in pheasants, $94,96,100$

saturated: unsaturated ratios, $89,96,100$, 104,108

Feeding trials

procedures for, 88

Flame spectrophotometry, 90

Flight and maintenance chow (FMC) chemical composition of, 89,101

Floury-2, 106

Food consumption

by experimental hens, $91,92,98$

procedures for measuring, 89

\section{G}

Gallus gallus (see chicken)

Gizzard, 95

Glands, 89-90, 94, 95, 96, 99, 100, 103-104, 105,108

Gonadal recrudescence, 105, 106

\section{H}

High-lysine corn

defined, 87

Hypothalamo-hypophyseal axis, 105, 108

Hypothalamus, 103

J

Japanese quail, 106

\section{K}

Kidneys, 95

Kjeldahl procedures, 90

Lagopus lagopus alascensis (see willow ptarmigan)

Lagopus lagopus scoticus (see red grouse)

Lauric acid, 96

Leucine, 87

Linoleic acid, 96, 104-105, 108 


\section{L (cont.)}

Linolenic acid, 96

Liver, 95, 100

Lysine

consumption of, 92, 93, 99

correlated with body weight, 93-94

determination of, 90

importance of in nutrition, 87, 103, 108

in experimental diets, 89, 101, 107

requirements for, 101,102

utilization of, 93,99

\section{M}

Magnesium, 89, 90

Meleagris gallopavo (see turkey)

Metabolizability coefficient defined, 92 for experimental diets, 92, 93, 98, 99, 107

Metabolizable energy (ME) requirements for, 101 supplied by experimental diets, 101

Methionine, 101, 102, 103

Microtus pennsylvanicus (see vole)

Minerals, 89, 90, 105, 108

Mortality related to diet, 106,108

Muscles (see sternal muscles)

Myristic acid, 96

\section{N}

\section{Nitrogen}

determination of, 90

Null hypothesis

level accepted or rejected, 90

O

Oleic acid, 96, 104-105, 108

Opaque-2, 87, 106, 107

Organs, 89-90, 94, 95, 99, 100

Ovary, 100

Oviduct, 100

Ovum, 100

P

Palmitic acid, 96

Palmitoleic acid, 96

Pancreas, 95
Parathyrnid glands

as indicator of negative calcium balance, 105,108

functions of, 105

mean weights of, 95,100

Parathyroid hormone, 105

Pectoralis thoracia, 89

Phosphorus, 89, 90

Potassium, 89, 90

Protein

consumption of, 92,98

correlated with body weight, 93,94

determination of, 90

in diets of wild pheasants, 102

in excreta, 92, 98

in experimental diets, 89,107

requirements for, 101, 102

utilization, 92-93, 98, 102

\section{$\mathbf{R}$}

Rats, 87

Red grouse, 105

Redpoll, 104

Ruffed grouse, 103

S

Sodium, 89, 90

Spleen, 95

Stearic acid, 96

Sternal muscles, 95, 100

Stress, 103

Supracoracoideus ventral head of, 89

Swine, 87

\section{$\mathrm{T}$}

Thymus glands, 85

Thyroid glands, 95, 100

Triglycerides, 104

Tryptophan, 87, 101, 102

Turkey, 87, 101, 102

\section{V}

Visceral fat (see fat deposits)

Vole, 103

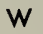

Willow ptarmigan, 105 


\section{Some Publications of the ILLINOIS NATURAL HISTORY SURVEY}

\section{BULLETIN}

Volume 30, Article 3.-Migrational Behavior of Mallards and Black Ducks as Determined from Banding. By Frank C. Bellrose and Robert D. Crompton. September, 1970. 68 p., frontis., 25 fig., bibliogr., index.

Volume 30, Article 4.-Fertilization of Established Trees: A Report of Field Studies. By Dan Neely, E. B. Himelick, and Webster R. Crowley, Jr. September, 1970. 32 p., frontis., 8 fig., bibliogr., index.

Volume 30, Article 5.-A Survey of the Mussels (Unionacea) of the Illinois River: A Polluted Stream. By William C. Starrett. February, tis., 8 fig., bibliogr., index.

Volume 30, Article 6.-Comparative Uptake and Biodegradability of DDT and Methoxychlor by Aquatic Organisms. By Keturah A. Reinbold, Inder P. Kapoor, William F. Childers, Willis N. Bruce, and Robert L. Metcalf. June, 1971. 12 p., frontis., 5 fig., bibliogr., index.

Volume 30, Article 7.-A Comparative Study of Two Components of the Poinsettia Root Rot Complex. By Robert S. Perry. August, 1971. 35 p., frontis., 10 fig., bibliogr., index.

Volume 30, Article 8.-Dynamics of Condition Parameters and Organ Measurements in Pheasants. By William L. Anderson. July, 1972. 44 p., frontis., 6 fig., bibliogr., index.

Volume 31, Article 1.-The Effects of Supplemental Feeding and Fall Drawdowns on the Largemouth Bass and Bluegills at Ridge Lake, Illinois. By George W. Bennett, H. Wickliffe Adkins, and William F. Childers. January, 1973. 28 p., frontis., 8 fig., bibilogr., index.

\section{BIOLOGICAL NOTES}

71.-A Synopsis of Common and Economic Illinois Ants, with Keys to the Genera (Hymenoptera, Formicidae). By Herbert H. Ross, George L. Rotramel, and Wallace E. LaBerge. January, 1971. 22 p., 27 fig., bibliogr.

72.- The Use of Factor Analysis in Modeling Natural Communities of Plants and Animals. By Robert W. Poole. February, 1971. 14 p., 14 fig., bibliogr.

73.-A Distributional Atlas of Upper Mississippi River Fishes. By Philip W. Smith, Alvin C. Lopinot, and William L. Pfieger. May, 1971. 20 p., 2 fig., 107 maps, bibliogr.

74. - The Life History of the Slenderhead Darter, Percina phoxocephala, in the Embarras
River, Illinois. By Lawrence M. Page and Philip W. Smith. July, 1971. 14 p., 10 fig., bibliogr.

75.-Illinois Birds: Turdidae. By Richard R. Graber, Jean W. Graber, and Ethelyn L. Kirk. November, 1971. 44 p., 40 fig., bibliogr.

76.-Illinois Streams: A Classification Based on Their Fishes and an Analysis of Factors Responsible for Disappearance of Native Species. By Philip W. Smith. November, 1971. 14 p., 26 fig., bibliogr.

77.-The Literature of Arthropods Associated with Soybeans. I. A Bibliography of the Mexican Bean Beetle, Epilachna varivestis Mulsant (Coleoptera: Coccinellidae). By M. P. Nichols and M. Kogan. Fehruary, 1972. 20 p., 1 fig., bibliogr.

78.-The Literature of Arthropods Associated with Soybeans. II. A Bibliography of the Southern Green Stink Bug, Nezara viridula (Linneaus) (Hemiptera: Pentatomidac). By N. B. DeWitt and G. L. Godfrey. March, 1972. 23 p., 1 fig., bibliogr.

79.-Combined Culture of Channel Catfish and Golden Shiners in Wading Pools. By D. Homer Buck, Richard J. Baur, Charles F. Thoits III, and C. Russell Rose. April, 1972. 12 p., 3 fig., bibliogr.

80.-Illinois Birds: Hirundinidae. By Richard R. Graber, Jean W. Graber, and Ethelyn L. Kirk. August, 1972. 36 p., 30 fig., bibliogr. 81.-Annotated Checklist of the Butterflies of Illinois. By Roderick R. Irwin and John C. Downey. May, 1973. 60 p., 3 fig., 98 maps, bibliogr.

82.-Lactate Dehydrogenase Isozymes of Darters and the Inclusiveness of the Genus Percina. By Lawrence M. Page and Gregory S. Whitt. May, 1973. 7 p., 5 fig., bibliogr.

\section{CIRCULAR}

46.-Illinois Trees: Their Diseases. By J. Cedric Carter. June, 1964. (Third printing, with alterations.) 96 p., frontis., 89 fig.

49.-The Dunesland Heritage of Illinois. By Herbert H. Ross (in cooperation with Illinois Department of Conservation). August, 1963. 28 p., frontis., 16 fig., bibliogr.

51.-Illinois Trees: Selection, Planting, and Care. By J. Cedric Carter. August, 1966. 123 p., frontis., 108 fig.

52.-Fertilizing and Watering Trees. By Dan Neely and E. B. Himelick. December, 1971. (Third printing.) 20 p., 9 fig., bibliogr.

53.-Dutch Elm Disease in Illinois. By J. Cedric Carter. October, 1967. 19 p., frontis., 17 fig.

List of available publications mailed on request

No charge is made for publications of the Illinois Natural History Survey. A single copy of most publications will be sent free to anyone requesting it until the supply becomes low. Costly publications, more than one copy of a publication, and publications in short supply are subjects for special correspondence. Such correspondence should identify the writer and explain the use to be made of the publication or publications. 